\title{
Service productisation: systematising and defining an offering
}

Dr Janne Harkonen, Dr Arto Tolonen, Professor Harri Haapasalo

Industrial Engineering and Management

University of Oulu

Oulu, Finland

\section{Abstract}

\section{Purpose}

The previous literature has indicated that the productisation of services may play a role in service management, although a certain level of obscurity still surrounds the concept. The purpose of this study is therefore to clarify the meaning of service productisation as well as to contribute to a greater understanding of the concept.

\section{Design/methodology/approach}

An inductive analysis was applied to thirteen instances of activities related to the productisation of services, with secondary data being analysed to identify practices relevant to service productisation and to examine their significance. The analysis is guided by an extensive literature review.

\section{Findings}

Service productisation has been found to play a role in systematising and tangibilising a service offering and its related processes as well as in formalising the processes and service offerings. The potential elements of service productisation have been identified and supporting evidence has been provided. The findings indicate that service productisation has a specific focus on the offering and its related processes, with the aim being to create a service product that can be sold, delivered and invoiced. Service productisation may utilise various practices and techniques, and customer orientation also plays a significant role. A typology of service productisation has been created by reflecting on its commercial and technical aspects.

\section{Practical implications}

This study has important implications for the service industry as it provides a structure and key considerations for productising services.

\section{Originality/value}

This study is one of the first to seek evidence for the concept of service productisation from multiple instances of service productisation as well as an extensive literature base. The typology created provides a context for discussing service productisation as well as reflecting on its commercial and technical aspects.

Keywords: Productisation, Developing, Reviewing and Defining Service Productisation, Service Offering, Service Modularity, Service Blueprinting 


\section{Introduction}

Managing services is crucial especially in case of large or expanding service businesses, but it also benefits organisations of a smaller scale. The service offering is the focal point of business performance, and the ability to explain the mechanisms of service offerings can prove beneficial for service management (Kwak and Kim, 2016). Apart from being viewed as an offering, service is also viewed as a process or as the exploitation of resources and competencies to gain benefits (Lush, 2011). Recently, there have been references in literature to the productisation of services, but the true positioning of the concept in the field of service and its role in relation to service offering and processes has remained somewhat unclear. Harkonen et al. (2015, p.70, p.71) have made the most detailed attempt at defining the concept of service productisation (SP):

Productisation is the process of analysing a need, defining and combining suitable elements into a product-like object, which is repeatable and comprehendible. Productisation activities cover those for commercial readiness to enable selling, delivering, using and invoicing. Productisation in the context of services addresses the objects of exchange that are typically abstract and intangible, and has a specific role in clarifying the service offering, creating replicability and enhancing understanding of the offering.

The anatomy of SP has been discussed by many authors, and it is often said to address the clarity of services and a certain level of systematisation (Chattopadhyay, 2012; Jaakkola, 2011; Lehtonen et al., 2015). The literature frequently discusses SP as a rather general process of offering productlike services to the market by combining and managing relevant service elements (Flamholtz, 1995; Harkonen et al., 2015; Jaakkola, 2011; Valminen and Toivonen, 2012). The positioning of SP has, however, remained somewhat unclear. For example, SP has been discussed as a specific type of service innovation in the previous literature (Hemple, 2015; Valtakoski and Järvi, 2016), while productisation activities have been interpreted as being positioned somewhere in the interface between service development and commercialisation (Harkonen et al., 2015). The service innovation in this context refers to ideas about how to best organise a solution to fulfil a customer need. However, the exact positioning among service development, service design, operations, service sales and marketing is not clear in the discussion as it currently stands. Additionally, specific operational definitions or understandings of what counts as productisation are generally lacking (Hemple et al., 2015).

Service offering (Andreassen et al., 2016; den Hertog et al., 2010) as well as the processes and components of service (Goldstein et al., 2002; Hakanen and Jaakkola, 2012) have been widely discussed in the literature. Nevertheless, regardless of the previous valuable service discussion and despite the increasing number of articles referring to SP and previous direct focus on service offerings and processes, there is still a certain level of obscurity about the SP concept. It remains unclear, for example, which activities are considered to be productisation. Even so, despite this lack of clarity in academic discussion, practitioners seem to be more confident about the concept. There remains a gap in the literature in the form of an unclear relationship or association between a service offering, the service process and the relation to SP.

This study aims to broaden and strengthen the understanding of the concept of SP by bringing together existing knowledge on the concept and analysing thirteen relevant instances of activities 
related to the productisation of services. This inductive analysis aims to clarify the elements of SP and the relation to service offering and processes.

The concept of SP has previously not been subject to sufficient empirical investigation. This study is supported by a thorough literature review covering the previous research concerning SP that has been published in journals. The literature covers all articles on SP found via Google Scholar, Scopus, Emerald and Science Direct. The findings of the literature review are complemented with additional supporting literature in order to create a frame of analysis, which is then employed to analyse instances of SP. The following research questions stem from the gaps identified in the past literature:

In service productisation, how important is the management of the service process and service offering to the ability to sell, deliver and invoice services?

How has the role of service productisation been presented in past literature?

What are the elements of service productisation and how do they contribute to a company's ability to manage services?

The remainder of the paper proceeds as follows: The next section presents a review of literature directly relevant to the concept of SP together with research propositions that are consistent with the research aims. This is followed by the construction of a frame of analysis based on the previous direct discussion of SP and the complementary literature. The methodology section describes how this study was conducted. The findings are then discussed based on the analysis of secondary data by presenting in-depth descriptions and a relevant synthesis. Finally, a typology of SP is presented, followed by the contributions, implications and limitations of the study as well as directions for future research.

\section{Literature review}

Over the past few decades, the literature has increasingly referred to SP, a concept that appears to be relatively new to service research, although it is seemingly widely used among practitioners and discussed in managerial magazines and seminars (Harkonen et al., 2015; Jaakkola, 2011; Valtakoski and Järvi, 2016). As a first step, Table 1 highlights how SP is understood in the literature.

Table 1. Examples of how service productisation is understood in the literature

\begin{tabular}{ll}
\hline Authors & Service productisation is understood as \\
\hline Lehtonen et al. 2015 & $\begin{array}{l}\text { "Practice of service formalisation and codification." To describe the processes that aim to tangibilise and systematise both } \\
\text { the service content and service process. However, the complete standardisation of service is not the aim of productisation, } \\
\text { but rather the development of basic processes and structures that can then be complemented with case-specific elements. } \\
\text { "The standardisation of the production and delivery processes of services is an approach that many service companies } \\
\text { undertake, moving from relationship-intensive customer projects toward selling-specific standardised offerings." } \\
\text { Specifying and standardising the service offering; tangibilising and concretising the service offering; and systemising and } \\
\text { standardising processes and methods. To make services easier to sell and buy via creating simple and tangible service offerings } \\
\text { that are easy to comprehend. To make the service process more controllable and manageable. } \\
\text { "The development of systemic, scalable and replicable service offerings." To improve competitiveness and performance. }\end{array}$ \\
$\begin{array}{l}\text { Chattopadhyay } 2012 \\
\text { Valminen and }\end{array}$ & $\begin{array}{l}\text { An activity whereby the service offering is made more "product like' through the systematisation of service components and } \\
\text { the systematisation of internal processes within an organisation. To gain efficiency, improved profitability and } \\
\text { competitiveness. } \\
\text { Standardisation of services, so essentially the same service product can be replicated many times over with minimal } \\
\text { variations. To make the service less fuzzy. } \\
\text { "Packaging of the service offering as a predefined series of modules or a unified offering to the clients." To rationalise the } \\
\text { service offering, how the services are delivered and the sales process involving standardised service components that are pre- } \\
\text { costed, market priced and pre-assured both individually and in combination. }\end{array}$ \\
\hline
\end{tabular}


Nagy 2013

Lukka and Partanen

2014

Artto et al. 2008

Ritala et al. 2013

Suominen et al. 2009

Gupta 2011

Simula et al. 2008

Rajahonka 2013

Flamholtz 1995

Flamholtz and

Aksehirli 2000

Flamholtz 2002

Flamholtz and Hua

2002

Flamholtz and Hua

2003

Flamholtz and

Kurland 2005

Saarela et al. 2013

Aapaoja et al. 2012

Ukko et al. 2011

Danson et al. 2005

Heaslip 2013

Harkonen et al. 2015

Valtakoski and Järvi 2016

Hemple et al. 2015

Anupam et al. 2006

Ardley and Quinn

2014

Arora et al. 2001

Bask et al. 2010

Bask et al. 2011

Cusumano 2008

Kim 2009

Kim and Yoon 2012

Kindström and

Kowalkowski 2014

Mattila et al. 2013

Saarela et al., 2014

Salmi et al. 2008

Skalen and Hackley

2011
Service companies provide more product-like solutions through the systemisation of service components. Includes developing formal service development processes with diverse stages (from idea generation to commercialisation). Developing well-defined service packages.

Relates to considerations regarding the content and pricing of services intended to provide adequate customer value while running a wealthy and profitable business.

Standardisation of service output and processes, service offering modelling and modularisation. To enable scale up and services to reach wider markets while retaining quality.

Standardising services and service processes. To emphasise quality, customer demand and market orientation.

Adding repeatability into services.

Defining, describing, improving, producing and continuously developing the offering so that customer benefits are maximised and the organisation's goals are achieved. Clarifying and rationalising the offering for the company (more efficient operations) and the customer (more appealing offering).

Modularising services into modules that can be combined based on customer needs, including basic and value added services. This is also linked to service processes that consist of standardised sub-processes.

The process of analysing the needs of current and potential customers in order to design the (products or) services that will satisfy their needs. The productisation process includes not only the design, but also the ability to produce it. For a service firm, the ability to produce involves the firm's service delivery system, that is, the mechanism through which services are provided to customers.

Clarifying the service portfolio. To provide structure and to be able to address internal and external needs.

Partially standardised and partially customised services: standard parts ensure efficient processes, while customisation ensures the fulfilment of customer requirements. To achieve better cost efficiency and improved customer orientation via the standardisation of services and service processes

A process in which a service idea is developed into a marketable entirety that has standardised and well-documented production phases. Can be modular and contain core, additional and supportive services.

Defining services based on the customer's requirements to the extent that customers can articulate them.

Defining the services so well that they are understood by customers and suppliers alike.

Productisation is the process of analysing a need and then defining and combining suitable elements into a product-like object, which is formalised, repeatable and comprehendible. Productisation in the context of services addresses the objects of exchange that are typically abstract and intangible. Productisation plays a specific role in clarifying the service offering, creating repeatability and enhancing understanding of the offering

Service productisation is formalisation type of service innovation that applies various techniques.

Productisation is identified as a kind of service innovation, which acts materially with respect to a product and its more widespread use and socially as a service in offering additional value to users by being more useable.

"Productisation to enhance and improve services, enable rapid service creation, and enable learning customer preferences."

Reduces abstract customer offerings or highly technical processes into a more standardised, controllable and easily exchangeable object.

"Developing products from the services."

Modularity from the service perspective is closely connected to the productisation of services.

Relates to controlling the heterogeneity of services through the standardisation of service modules.

Productising services is involved in activities enabling the more efficient delivery of services. The productisation of services can come from component or design reuse, as well as standardised process frameworks.

"Productisation of services includes standardisation and modularisation of service processes."

"Moving from services to products, making services more product-like."

Tangibilising - A firm can launch many new services while maintaining its product-centric business logic and managing its service business in a product-like manner.

Making the service package more understandable.

The goal of productisation is to clarify the service portfolio so that, after first contact with a customer, the personnel can guide that customer to the right service/specialist. The intention is to minimise ad hoc services and develop more specialised services according to the lifecycle.

"Giving more tangible features for the service."

"Making services more product-like, tangibilising and concretising the service offering."

The issues discussed in relation to SP are not completely new, since some similarities exist to previous discussions under the headings of the industrialisation of services (Levitt, 1976), standardisation of services (Bebko, 2000) and commodification of services (Nagy, 2013). This type of systematic approach to services has previously been said to involve a service offer that fulfils customer needs, the logic of service processes and the service system's ability to support the service process (Edvardsson, 1997; Valminen and Toivonen, 2012). Such a systematic approach to services would allow for a specific focus on customer needs, although it does not directly address how the relevant customer information is gathered as input (Nagy, 2013). The role of SP has not been 
discussed in depth in the literature and hence it is somewhat unclear, which raises questions regarding the elements of SP that touch on its role as well as the systematisation, tangibilisation and formalisation of services.

\subsection{Framework of potential SP elements}

This section presents a framework of the potential elements of SP based on identifying characteristics found in the existing literature. The discussion is supported by literature that both directly and indirectly concerns SP. In the later sections of this paper, this framework has been further used to analyse thirteen relevant instances of activities related to the productisation of services.

Customer orientation is discussed in the context of the systematisation of services and service processes (Aapaoja et al., 2012; Nagy, 2013). Customer value and customer benefits are also linked to customer orientation (Artto et al., 2008; Danson et al., 2005; Simula et al., 2008), to which, for example, modularity is linked via meeting customer needs (Rajahonka, 2013). In general, analysing the needs of current and potential customers is essential, whereas the question of how such an analysis should be approached is not necessarily answered (Flamholtz, 1995, 2002; Flamholtz and Aksehirli, 2000; Flamholtz and Hua, 2002, 2003; Flamholtz and Kurland, 2005; Harkonen et al., 2015).

Customer orientation plays an important role in service companies due to the service characteristics (Kelley, 1992). The mechanisms of customer orientation involve the use of customer contact employees, although the literature has its deficiencies in this regard (Hennig-Thurau and Thurau, 2003). The employees' capability to capture customer information as well as to integrate the company's operations and marketing functions into the service delivery process is emphasised (Jayaram and Xu, 2016). The prior literature often links customer orientation to service delivery or sales and marketing, but it has also been analysed in the context of the service development process (Alam and Perry, 2002), which provides linkages to productisation via the service offering. Drucker (1954), a pioneering proponent of customer focus, highlights how the entire organisation, not just a single business process, should focus on the customer. Hence, customer orientation whereby the customer's interests come first, without excluding those of the owners, managers and employees, is vital (Deshpande et al., 1993).

Customer orientation is also discussed in relation to market-based information regarding customers, in addition to other factors linked to the making of coordinated decisions (Newman et al., 2016; Slater et al., 2010; Wang et al., 2016). The service concept has previously been said to involve describing customer needs as well as how they can be met in terms of the content or design of the service package, which is also referred to as a service prototype. The service concept is directly linked to the customer perspective wherein the primary and secondary needs translate into the service components (Edvardsson, 2005; Edvardsson and Olson, 1996; Edvardsson et al., 2005; Goldstein et al., 2002; Grönroos, 2001). In fact, the service concept is often seen to represent a common link between new service development, service design and service innovation (Goldstein et al., 2002). Overall, customer orientation is a multifaceted topic that can be approached from a variety of perspectives. The previous related discussion has led to the following research proposition (RP):

RP1: Customer orientation focuses on the need aspect in relation to SP, links to service offering and processes and involves both internal and external customer perspectives. 
The service process refers to the chain of activities that are required in order to produce a service (Edvardsson, 1997). Service process can be categorised in different ways, for instance, technical processes, activities performed by personnel and activities conducted at the customers' premises. They could also be categorised into main, support and management processes, as well as into customers' processes and suppliers' processes. Indeed, in terms of services, a line of visibility needs to be considered between what customers should see and what they should not see (Edvardsson and Olson, 1996; Grönroos, 2008).

The service process is an important service component, since modelling services supports the systematic approach to services (Edvardsson, 1997; Valminen and Toivonen, 2012). Describing service processes is said to support the development of basic processes and structures that can be complemented with case-specific elements (Lehtonen et al., 2015). Further, Valminen and Toivonen (2012) consider productisation to be the systematisation of the internal processes within an organisation. Hence, increased clarity regarding services and the relevant processes is achieved while creating replicability (Harkonen et al., 2015).

The service process entails descriptions of activities (Edvardsson and Olson, 1996; Grönroos, 2008), since stable quality is seen to be achieved via well-defined processes (Chattopadhyay, 2012). Productisation contributes to both effectiveness and profitability via systemisation and routines (Jaakkola, 2011). For example, Rajahonka (2013) links the modularising of services to service processes using systematised sub-processes. Additionally, Jaakkola (2011) refers to the systemising and standardising of processes and methods. The complete standardisation of service processes is, however, not necessarily the aim (e.g. Lehtonen et al., 2015). Thus, some consider productisation to extend beyond merely clarifying and documenting (Aapaoja et al., 2012; Andreini et al., 2015; Ritala et al., 2013; Suominen et al., 2009; Ukko et al., 2011).

Process modularisation is used to clarify service processes in order to understand their structure (Prilla et al., 2012). In addition to such a structural understanding, recognising customer-specific activities, resources and competencies is critical (Carlborg and Kindström, 2014). Utilising approaches such as service blueprinting (Shostack, 1984) has been found to be beneficial for achieving clarity; for example, Fließ and Kleinaltenkamp (2004) make a distinction between customer-induced and customer-independent activities when addressing service processes. Service mapping is another tool used to clarify service processes by means of flowcharts (KingmanBrundage et al., 1995); however, it only reflects the operational/managerial aspects. Further, service process modelling can also prove useful in analysing and clarifying service processes (Silvestro, 1999). The following research proposition is presented in relation to SP and service processes:

RP2: Service processes relate to the technical side of a service, are of importance to SP and are mostly of an internal focus, with links to sub-processes and resources.

Task orientation is not particularly apparent in the service literature. While working methods are occasionally referred to, they are not widely discussed (Teare et al., 1997; Wallace et al., 2000). The literature in the context of working methods is scarce, potentially due to working methods not being intended to form rigid processes but rather to function more like principles and guidelines necessary to inspire and drive service work (Bettiol et al., 2012). Indeed, working methods do not seem to be widely discussed, at least not in general terms, although they are considered to be related to SP.

The service offering, that is, the configuration of suitable service sales items or the elements of a service, is a highly relevant theme in the context of services. The service offering is in fact 
typically discussed as an important service component (Edvardsson, 1997), with literature on productisation directly discussing defining, specifying, describing and systematising services (Chattopadhyay, 2012; Flamholtz, 1995; Jaakkola, 2011; Lukka and Partanen, 2014; Lehtonen et al., 2015; Simula et al., 2008; Valtakoski and Järvi, 2016) and referring to the need to make the service offering more product-like (Harkonen et al., 2015; Hemple et al., 2015; Nagy, 2013; Valminen and Toivonen, 2012).

Additionally, the modular structure is directly discussed in the context of productisation, including core, additional and supportive services (Aapaoja et al., 2012; Leon and Davies, 2008; Rajahonka, 2013; Saarela et al., 2013; Ukko et al., 2011). The ultimate service product that is delivered represents the core service that provides benefits to customers, which thus constitutes the core benefits the customer seeks (Baltacioglu et al., 2007).

Further, Wang (2011) emphasises the importance of focusing on the core service and its quality before considering extras. A number of supporting or additional services may be required together with the core service; for example, Grönroos (1982) refers to auxiliary services. These can be produced by suppliers or the service provider (Baltacioglu et al., 2007). The combination of service elements or sales items is often addressed as a service, that is, as the subject of transactions. In addition, facilitating services that serve as enablers for using the core service may also exist (Grönroos et al., 2000). The division into core and supporting services, however, may not be static from the customers' perspective but may appear according to different situations. The customer focus may be on value creation, to which both core and support services contribute (Roos and Edvardsson, 2008).

It is also argued that leading practitioners do not invest heavily in solely improving core service attributes but may instead equally emphasise buyers' evaluation, choice and needs (Johne and Storey, 1998). The importance of defining the core service attributes prior to the formulation of the service delivery system or supply chain process for services is emphasised (Cowell, 1988). Both core and supporting services are considered during service concept development, together with customer needs (Edvardsson and Olsson, 1996). This has been distilled into the following proposal:

RP3: SP focuses on the product nature of the service offering, the service product being a configuration of elements - core, supporting and additional - that provide benefits to customers. In the SP context, the customers' have visibility over the service product configuration.

The existing literature considers service modularity in conjunction with productisation. SP is seen as the packaging of the service offering as a predefined series of modules (Leon and Davies, 2008), with modularisation being emphasised by various authors (e.g. Nagy, 2013; Rajahonka, 2013; Ritala et al., 2013; Valminen and Toivonen, 2012). However, productisation does not necessarily entail modularisation. Service modularity is more of a tool for structuring services internally (Rahikka et al., 2011) and it can support the manageability of complex services (Bask et al., 2010b).

Modularity provides the basis for customisation, customer choice, effective service development and outsourcing, while a competitive advantage is often the result of unique service modules (Voss and Hsuan, 2009). Hence, modularity can be seen to facilitate the management of heterogeneity (Pekkarinen and Ulkuniemi, 2008). Modularity can also help when the rules for combining services are too complex for customers and employees to understand (Docters et al., 2004). An architecture is required to describe the service system's structure, as well as interfaces describing the interaction of the modules (Böttcher and Klingner, 2011). 
Additionally, the role of service experience is emphasised alongside considerations of modularity (Tuunanen et al., 2012). The important attributes of modular services include objectification, coordination, managing complexity and value co-creation, some of which are also presented as the aims of productisation. These attributes aid in making the service characteristics explicit, defining the necessary resources and responsibilities and defining interfaces between customers and service providers (Ulkuniemi and Pekkarinen, 2011). Modularisation addresses complexity while allowing for customer-specific adaptation, which leads to manageable complexity and a decrease in the cost of producing services (Hyötyläinen and Möller, 2007). Eissens-van der Laan et al. (2016) identify four decomposition logics for modular services, namely single-level outcome-orientation, single-level process-orientation, multilevel outcome-orientation and multilevel combined-orientation. Service process modularisation enables companies to generate market impact through innovative offerings characterised by the reuse and variation of existing service processes (Tuunanen and Cassab, 2011). Bask et al. (2010) argue that modularity from the service perspective is closely connected to SP, while the modularity discussion concerning services is influenced by the earlier product modularity discussion. Modularisation is also seen as a key process for service innovation (Van der Aa and Elfring, 2002), since insufficiently modularised services may hinder service innovation (Dörner et al., 2011), while the modularisation of both services and the service system is critical (Böttcher and Fähnrich, 2011).

Service blueprinting appears to be a relevant practice for service productisation involving various techniques (Valtakoski and Järvi, 2016). In essence, blueprinting corresponds to the same idea as productisation, although these concepts are not always positioned in relation to each other (Valminen and Toivonen, 2012). More often, the techniques used in productisation are not named.

Service blueprinting is a customer-focused approach that allows for the exploration of issues relevant to creating or managing services (Shostack, 1984). The customer actions represent a particular focus, while the service blueprint acknowledges visible onstage actions, invisible backstage actions and support processes (Bitner et al., 2008). Service blueprints thus assist in mapping the steps of a service and in tangibilising the service concept (Menor et al., 2002). Service blueprints also support the understanding of services, identify potential points of failure in the process and facilitate communication (Kim and Meiren, 2010). The actual service may, however, deviate from the blueprint in terms of its duration, quality and level of customer satisfaction as the prerequisites for the service and service production deviate (Edvardsson and Olson, 1996).

The literature considers whether assessing customer benefit is a relevant characteristic of SP, particularly with reference to analysing the needs of current and potential customers and defining the services based on customer needs while discussing productisation (Danson et al., 2005; Flamholtz, 1995, 2002; Flamholtz and Aksehirli, 2000; Flamholtz and Hua, 2002, 2003; Flamholtz and Kurland, 2005; Harkonen et al., 2015). Nevertheless, a certain sense of vagueness exists when productisation is indicated to relate to considerations of providing adequate customer value (Artto et al., 2008), emphasising customer demand (Suominen et al., 2009) or maximising customer benefit (Simula et al., 2008). Hence, a greater understanding is required. Generally, in services, customers' perceptions, which are often referred to as customer benefits, can be seen as the antecedents of customer satisfaction, which influence customer behaviour in relation to using the service again (Gustafsson and Johnson, 2004; Patterson and Spreng, 1997). Prior experience and/or education influence customers' benefit expectations (Hoch and Deighton, 1989), which emphasises the importance of understanding customers' background. 
The success of the service is influenced by a variety of factors in addition to the service itself, of which the market-related factors may include market potential, volumes and competition (de Brentani, 2001). If a service is further divided into process- and result-related factors, the latter may include the market-related factors, where the market potential is based on market growth rates and the market volume potential (Lightfoot and Gebauer, 2011). Edvardsson et al. (2013) discuss market acuity as a service development competence relevant to a firm's ability to view the competitive environment and anticipate and respond to evolving needs. There are indications that productisation might emphasise market orientation (Suominen et al., 2009), although solid evidence in this regard is lacking. Market orientation is, however, considered to be related to SP.

The success of a service can also be influenced by factors related to service development, including evaluating and testing the service (de Brentani, 2001). Generally, piloting services, which involve service testing and pilot runs, are linked to new service development wherein the customers' input is acquired through their participation in testing the services and proposing improvements (Alam and Perry, 2002). In such a way, service providers can test their service blueprints, implement design changes and refinements, prove the service under real-life conditions and determine users' level of acceptance (Alam, 2002). Magnusson et al. (2003) use the term 'user involvement' to refer to similar activities, which imply a positive effect on service quality if properly managed, as well as offering possibilities for obtaining valuable user information. In the wider sense, piloting and testing services relate to customer integration, which can aid in identifying and creating effective services (Edvardsson et al., 2012). The literature is not completely clear regarding the relation between productisation and the piloting of the productised services. Indeed, piloting potentially falls under the category of productisation employing various techniques (Valtakoski and Järvi, 2016). Piloting is, however, considered to probe the nature of SP. Thus, the following is proposed:

RP4: SP involves various practices and techniques, including modularisation, blueprinting, assessing customer benefits, analysing market related factors and piloting services.

The prior literature provides indications that certain elements are relevant to service productisation, of which some appear more strongly relevant than others. Table 2 illustrates the identified framework of the potential elements of SP in the form of nine assertions. The identified potential elements may not be exhaustive and all of them require further investigation. The possible hierarchy of the presented elements is ignored.

Table 2. Framework of potential SP elements 


\section{Methodology}

The research approach used in this study is qualitative and it applies inductive logic. The approach is influenced by Strauss and Corbin's (1997) work on grounded theory development, according to which the researcher allows the theory to emerge from the data. The concept of an inductive analysis here refers to a research approach that relies on detailed readings of data in order to derive concepts, themes or a model by means of interpretation. The study has been completed by following the detailed guidance on a general inductive approach offered by Thomas (2006), which is guided by objectives or questions outlined by the researcher, condenses data into a brief format, establishes links between the research objectives and the summary findings and develops a model or theory of findings that are evident in the data. In this study, the analysis is guided by the findings of a thorough literature review. This approach has been used by numerous authors working in a variety of fields, which indicates that it is not tied to any specific discipline and is hence appropriate for multidisciplinary work. Additionally, empirical data can be obtained from either primary or secondary sources. Table 3 details the overall approach adopted in this study. The benefit of using this particular research approach is that the findings are intimately tied to the evidence (Thomas, 2006).

An extensive literature search and investigation guides the analysis made as part of this study. Standards typical to systematic literature reviews are therefore applied when analysing all the available research on the productisation of services (Fink, 2004; Kitchenham, 2004). The inclusion criteria for the literature were certain selected keywords and their appearance in articles published in peer-reviewed journals. The utilised keywords contained all the grammatical forms and spellings of the phrase 'productisation of services.' Keyword searches were conducted on Google Scholar, Scopus, Emerald and Science Direct. Published journal articles available through the searched databases at the time of the search were included, while books, business periodicals, conference proceedings and other materials were excluded. Studies were selected only if the keywords appeared in the text, and they were excluded if they only appeared in the list of references or within the biographies. The reference lists of the identified articles were reviewed to aid in locating additional papers, which resulted in some beneficial findings. The identified articles were read carefully in order to analyse the content relevant to SP and to analyse their relevance. As the terminology surrounding the studied topic has not been firmly established, additional searches were also undertaken to reveal any related discussions. The search procedure was repeated four times during the research process to ensure that no relevant articles had been missed and that recent publications had been included.

This procedure yielded a total of 102 relevant journal articles that were identified through the utilised databases and search engines. Content related to the productisation of services was analysed systematically and qualitatively in order to obtain an adequate understanding. A total of 60 articles were discarded due to their content and/or discussion on productisation being limited. Thus, a total of 42 articles were included in the final analysis, all of which are cited in this paper. In addition, some complementary discussions found outside these articles have also been included.

Secondary data described in Appendix A was also gathered and utilised in this study. The data originates from a number of publicly available sources that relate to the studied topic and describe 13 individual instances of activities related to the productising of services. The data sourcesunpublished university theses - were selected as they seemed to elaborate on service productisation the most. The contents of each source were analysed carefully and only those parts that contained empirical material were utilised in the analysis. Any other parts, including literature-based material 
and prior researchers' own thinking and contemplation, were ignored. Hence, this study only analyses material where adequate, non-tarnished data were available for analysis.

Analysing secondary data can be seen as appropriate in this context as it allows the researcher to use existing data that was collected for the purpose of a prior study. New research questions or alternative perspectives may then be used to pursue interests that vary from the original purpose behind the data collection (Heaton, 2008; Hinds et al., 1997; Szabo and Strang, 1997; Thorne, 1990). According to Harris (2001), this type of data can come from a variety of sources, including published research, various documents and reports. Qualitative analyses of data composed of interviews, observations and possibly some other evidence have previously been conducted in areas such as health research (Gladstone et al., 2007), industry and innovation research (Kristinsson and Rao, 2008) and operational research (Samaddar et al., 2006). Secondary data can be particularly beneficial in case of difficulties with access and sensitive situations, and it can reduce the distortion caused by imperfect recall and social desirability bias (Harris, 2001). There can also be advantages in terms of cost (Cowton, 1998), possibilities for wider research access (Liedtka, 1992) and credibility (Nachmias and Nachmias, 1987).

Table 3. Research methodology

\begin{tabular}{|c|c|}
\hline \multicolumn{2}{|l|}{ Analysing Past Literature } \\
\hline Extensive literature review & $\begin{array}{l}\text { To provide focus and a domain of relevance for conducting the analyses, but } \\
\text { not a set of specific expectations. } \\
\text { Standards typical of systematic literature reviews (Fink, 2004; Kitchenham, } \\
2004 \text { ). } \\
\text { Keyword searches in Google Scholar, Scopus, Emerald and Science Direct. }\end{array}$ \\
\hline \multicolumn{2}{|l|}{ Research Design } \\
\hline Flexible research design & $\begin{array}{l}\text { To allow the findings to "unfold, cascade and emerge" (Lincoln and Guba, } \\
\text { 1986, p. 210). }\end{array}$ \\
\hline Characteristics & Exploratory perspective to allow the building of rich descriptions of content. \\
\hline $\begin{array}{l}\text { Use of a priori constructs, theory or } \\
\text { hypotheses }\end{array}$ & $\begin{array}{l}\text { Harkonen et al. } 2015 \text { utilised for the initial coding. No a priori theory or } \\
\text { hypotheses specified. }\end{array}$ \\
\hline Unit of analysis & Activities for productising services. \\
\hline \multicolumn{2}{|l|}{ Conduct } \\
\hline Data collection & $\begin{array}{l}\text { Qualitative secondary data are collected via open repositories and keyword } \\
\text { searches. All the identified documents are carefully read to judge their } \\
\text { suitability. The data comprise interview and other data. }\end{array}$ \\
\hline $\begin{array}{l}\text { Selection and number of instances of } \\
\text { SP }\end{array}$ & $\begin{array}{l}\text { Criterion sampling. Publicly available theses in Finland with relevant and } \\
\text { adequate data, with as rich data as possible. Adequate enough number. }\end{array}$ \\
\hline \multicolumn{2}{|l|}{ Analysis } \\
\hline Analysis strategy & $\begin{array}{l}\text { 1) Analysis guided by the findings of the literature review. } \\
\text { 2) Development of categories from the data into a framework. } \\
\text { 3) Findings based on the researchers' interpretations. }\end{array}$ \\
\hline Coding & $\begin{array}{l}\text { 1) Initial reading of the data on the instances of SP. } \\
\text { 2) Flagging activities relevant to service productisation. Any remarks were } \\
\text { kept separate from the evidence. } \\
\text { 3) Labelling to create categories. } \\
\text { 4) Content analysed across the instances by means of the created labelling. } \\
\text { 5) Reducing overlaps and redundancy. } \\
\text { 6) Creating a model featuring the most important categories. }\end{array}$ \\
\hline Logic & Inductive logic to allow the data to explain. \\
\hline Analysis outcome & $\begin{array}{l}\text { Themes most relevant for the research objectives identified and a typology of } \\
\text { SP synthesised. }\end{array}$ \\
\hline Enfolding literature & Comparison with the literature, similarities and conflicts. \\
\hline
\end{tabular}


The analysis conducted as part of this study is consistent with both data condensation and data display (Miles and Hubermann, 1994). Data condensation refers to analytical choices regarding which parts of the data are relevant, while data display refers to analysis activities in the form of tables or other illustrations that aid in understanding the data. Nevertheless, it is the general inductive approach discussed by Thomas (2006) that has been primarily followed in this study.

The literature review helped guide the analyses, which were conducted through multiple readings of the data and formulating interpretations. Even though the findings are based on an understanding of the literature, they arise directly from the analysed data. The literature-based understanding hence provides a focus or domain of relevance for the analyses but not the expected findings.

The main mode of analysis employed was the development of categories derived from the data into a framework. In the context of 13 instances of SP, the content of unpublished university theses was analysed and labelled. Any overlapping and/or redundancy was reduced through the analysis cycles. The framework contains the key themes and processes identified by the researchers who coded the data. The categories are labelled so that they carry an inherent meaning or reflect the features of the category. This has been done in order to enable the identification of the nature of SP within and across the data as presented in the empirical material. The characteristics that appear relevant to SP were carefully compared as patterns, themes and trends in an effort to adequately capture them.

The findings resulting from the multiple interpretations were naturally shaped by the assumptions and experiences of the researchers. Hence, the researchers had to make decisions regarding the importance of the findings in order for those findings to be usable. There also exists the possibility that different researchers might produce findings that are not identical. However, the development of categories resulting in a framework conveys the key themes and processes relevant to SP. The categories have been described through the presentation of suitable evidence rather than through mere labelling. In order to ensure adequate traceability, the categories are divided into suitable sub-components so as to indicate the nature of the appearance of the related SP content in the analysed material. Each instance of SP is signposted by a specific letter (A-M) to indicate how each of them is positioned among the identified categories. Each category has links to other categories, and they may have commonalities as well as relationships. No particular hierarchy among the categories has been considered.

The characteristics apparent in the data were divided into categories of elements and then further into a set of relevant sub-components. The researchers played different roles so that their initial interpretations were analysed to understand whether the identified practices are relevant to SP. The credibility of the findings was established through peer debriefings, while the data were compared with the findings and interpretations in order to ensure dependability. Overall, the analysis was expected to provide similar rather than contrasting results.

The process of shaping the findings is more judgemental in this type of research, since the researchers cannot use statistical tests. The research team is therefore responsible for judging the strength and consistency of the articulated relationships. Naturally, the readers may also apply their own standards in assessing the logic and the findings. Consequently, qualitative data is especially useful in understanding relationships. The findings are presented as elements of SP by simultaneously indicating which of the 13 analysed instances of SP provide either full or partial support for the particular findings, while also indicating whether the findings are not supported by some instances or no relevant data were found. In addition, literature that is relevant to the phenomenon of interest was utilised to support the interpretations. Research streams that are directly related to SP and the services field in general have been used to support the findings that 
emerge from the data in order to confirm their relevance to SP. Each set of findings is presented as emerging from the sources and then compared to the existing literature. Finally, a typology of SP has been extracted based on the findings, and SP is presented and discussed in the context of commercial and technical service product portfolios.

The research sample is composed of 13 instances of SP activities - data originally utilised for unpublished university theses - consisting of a number of different types of services. The sample should prove adequate because the samples to be utilised in qualitative research are discretionary. The research objects, although few in number, were studied thoroughly. The emphasis is on the quality of the input material, but the size of the sample must be adequate for the type of analysis and interpretation (Patton, 2002). Thirteen instances of SP activities provided variety while still constituting a manageable sample; nevertheless, the incremental learning proved to be rather minimal. Adding more data would only be justified if the data is of exceptional quality.

\section{Findings}

The findings of this study have been reported as elements of service productisation based on the patterns, themes and trends identified within and across the data. The framework created on the basis of the literature has been used to support the analysis. The findings are reported by grouping the evidence that support the identified elements and by presenting adequately rich details. The instances of SP have been indicated (A-M) so that the elements can be tracked back to the individual instances if necessary. The later synthesis section show the relation between the empirical findings and the previous literature. To further address these findings, the appropriate literature has been cited and its relevance to SP and/or mismatches between the literature and the findings have been noted. The findings have then been further synthesised and a typology has been formulated to provide a clearer context for SP.

\subsection{Elements of service productisation}

The elements of SP as revealed through the analyses include: customer orientation; clarifying and documenting service processes; describing and documenting working methods; defining the service offering and assessing core, supporting and additional services; modularisation of services; service blueprinting; assessing customer benefit, market potential, possible volumes and competition and piloting productised services. All these elements and the nature of their appearance through the 13 analysed instances of SP are presented in Table 4.

Table 4. Elements of service productisation by instances of SP

\begin{tabular}{|c|c|c|c|c|c|c|c|}
\hline 1 & Customer orientation & \multicolumn{3}{|c|}{$\begin{array}{c}\text { Direct } \\
(\mathrm{A}, \mathrm{B}, \mathrm{C}, \mathrm{D}, \mathrm{H}, \mathrm{K}, \mathrm{L}, \mathrm{M})\end{array}$} & \multicolumn{3}{|c|}{$\begin{array}{c}\text { Indirect } \\
(\mathrm{E}, \mathrm{F}, \mathrm{G}, \mathrm{I}, \mathrm{J})\end{array}$} \\
\hline 2 & Service processes & \multicolumn{3}{|c|}{$\begin{array}{c}\text { Company original } \\
(\mathrm{A}, \mathrm{B}, \mathrm{C}, \mathrm{D}, \mathrm{E}, \mathrm{G}, \mathrm{H}, \mathrm{I}, \mathrm{J}, \mathrm{K}, \mathrm{L}, \mathrm{M})\end{array}$} & \multicolumn{3}{|c|}{$\begin{array}{l}\text { Defined by an external body } \\
(\mathrm{F})\end{array}$} \\
\hline 3 & Working methods & \multicolumn{2}{|c|}{$\begin{array}{c}\text { Directly } \\
(\mathrm{A}, \mathrm{D}, \mathrm{H}, \mathrm{K})\end{array}$} & $(\mathrm{B}$, & & \multicolumn{2}{|c|}{$\begin{array}{c}\text { No indication } \\
(\mathrm{E}, \mathrm{G}, \mathrm{I})\end{array}$} \\
\hline 4 & $\begin{array}{l}\text { Core-, supporting- and } \\
\text { additional elements (defining } \\
\text { service offering) }\end{array}$ & \multicolumn{3}{|c|}{$\begin{array}{c}\text { Defined } \\
(\mathrm{B}, \mathrm{C}, \mathrm{D}, \mathrm{H}, \mathrm{K}, \mathrm{M})\end{array}$} & & \multicolumn{2}{|c|}{$\begin{array}{c}\text { In progress } \\
(\mathrm{A}, \mathrm{E}, \mathrm{F}, \mathrm{G}, \mathrm{I}, \mathrm{J}, \mathrm{L})\end{array}$} \\
\hline 5 & Modularisation & \multicolumn{3}{|c|}{$\begin{array}{c}\text { Directly addressed } \\
(\mathrm{A}, \mathrm{B}, \mathrm{E}, \mathrm{G}, \mathrm{H}, \mathrm{I}, \mathrm{J}, \mathrm{K}, \mathrm{L}, \mathrm{M})\end{array}$} & & \multicolumn{2}{|l|}{$\begin{array}{l}\text { Indirectly } \\
(\mathrm{C}, \mathrm{D}, \mathrm{F})\end{array}$} \\
\hline 6 & Service blueprinting & \multicolumn{2}{|c|}{$\begin{array}{c}\text { By name } \\
(\mathrm{C}, \mathrm{E}, \mathrm{H}, \mathrm{L})\end{array}$} & \multicolumn{2}{|c|}{$\begin{array}{c}\text { Otherwise } \\
\text { understood } \\
(\mathrm{A}, \mathrm{B}, \mathrm{D}, \mathrm{F}, \mathrm{G}, \mathrm{J}, \mathrm{K}) \\
\end{array}$} & \multicolumn{2}{|c|}{$\begin{array}{c}\text { Not discussed } \\
(I, M)\end{array}$} \\
\hline 7 & Assessing customer benefit & $\begin{array}{l}\text { Feedback/ } \\
\text { experience } \\
(\mathrm{B}, \mathrm{C}, \mathrm{E}, \mathrm{F})\end{array}$ & $\begin{array}{c}\text { Benefit clarified } \\
\text { via } \\
\text { productisation } \\
(\mathrm{K}, \mathrm{L})\end{array}$ & Syst & & $\begin{array}{l}\text { Known, but } \\
\text { not clarified } \\
(\mathrm{D}, \mathrm{G}, \mathrm{J}, \mathrm{M})\end{array}$ & $\begin{array}{c}\text { Not } \\
\text { clarified } \\
(\mathrm{H}, \mathrm{I})\end{array}$ \\
\hline 8 & Market potential & \multicolumn{3}{|c|}{ Clarified during productisation } & & \multicolumn{2}{|c|}{ Not discussed } \\
\hline
\end{tabular}




\begin{tabular}{|c|l|c|c|}
\hline & & $(\mathrm{B}, \mathrm{D})$ & $(\mathrm{A}, \mathrm{C}, \mathrm{E}, \mathrm{F}, \mathrm{G}, \mathrm{H}, \mathrm{I}, \mathrm{J}, \mathrm{K}, \mathrm{L}, \mathrm{M})$ \\
\hline 9 & Volumes & $\begin{array}{c}\text { Not clear } \\
(\mathrm{D}, \mathrm{J})\end{array}$ & $(\mathrm{A}, \mathrm{B}, \mathrm{C}, \mathrm{E}, \mathrm{F}, \mathrm{G}, \mathrm{H}, \mathrm{I}, \mathrm{J}, \mathrm{K}, \mathrm{L}, \mathrm{M})$ \\
\hline 10 & Competition & $\begin{array}{c}\text { Clarified } \\
(\mathrm{B}, \mathrm{D})\end{array}$ & Not clarified \\
& & (A, C, E, F, G, H, I, K, L, M) \\
\hline 11 & Piloting & To obtain feedback \\
& & $\mathrm{B}, \mathrm{C}, \mathrm{D}, \mathrm{H}, \mathrm{K}, \mathrm{L}, \mathrm{M})$ & $(\mathrm{A}, \mathrm{E}, \mathrm{F}, \mathrm{G}, \mathrm{I}, \mathrm{J})$ \\
\hline
\end{tabular}

The data indicates that many of the elements are clearly related to the concept of SP.

Finding 1. Service productisation appears to play a role in systematising and tangibilising a service offering and its related processes. The creation of a level offormalisation, even to the extent of standardisation, also appears to be relevant to service productisation.

\subsubsection{Customer orientation}

Customer orientation appears to be one of the fundamental aims of productising services. Services are developed in order to meet the needs of customers through productisation, which entails analysing and describing services based on customer needs (A, B, H and M). The following comment exemplifies this: "services were divided into three categories based on customer needs while analysing the service offering during productisation." Nevertheless, the mechanism for clarifying customers' needs was not presented clearly in any of the analysed instances, and defining customers' requirements was experienced as challenging. Involving customers in the productisation process was, however, emphasised as important: "the most important part of successful productisation is involving customers. " Hence, a strong understanding of customers and the ability to develop services accordingly appears to be essential.

The backgrounds of employees in companies productising services were indicated to have some influence on the customer orientation. For example, employees with a marketing and sales background were seen to emphasise customers' viewpoints more strongly than those with a technical background. However, "Customers are not necessarily aware of deficiencies in their own requirements and are not willing to pay for taking the requirements to a better level," which may influence the productising of services.

A clear and structured service offering is necessary to either avoid problems with the customer interface or to be able to better present the services to customers ( $\mathrm{C}$ and $\mathrm{E}$ ), for example, " $A$ fragmented service product structure is perhaps the dominant reason for problems in this area." Formulating services to appeal to different service groups can help in enhancing customer understanding in terms of both content and cost, and it can also help to better understand the benefits from the customer's perspective (C, K, L and M): "As a starting point for productisation, the services were divided into two separate areas based on their differences." Productisation is seen to enable the more appropriate addressing of different service levels should the varying needs be based on customer desires or the criticality of the service, whilst there were indications that prior to the use of productisation, customer orientation was addressed via tailoring ( $G$ and $I$ ). Depending on the service type, however, the customer orientation may appear slightly different in some instances ( $\mathrm{F}$ and $\mathrm{J}$ ). Service quality, which can be defined by agreements and meeting set criteria, has an impact on customer satisfaction. In this case, offering the service to customers is not particularly emphasised, while an inadequate service provision can also have negative implications. Regardless of the differences among the service types, the emphasis on customer orientation is visible in all the analysed instances. Customer orientation also appears outside of productisation activities, with some instances indicating named customer representatives as a primary contact 
point during the service provision (e.g. C). Additionally, the optimisation of the customer value created was attempted by prioritising activities (K).

Finding 2. Customer orientation plays an underlying role in SP to ensure that the customers' needs and relevant perspectives are acknowledged.

\subsubsection{Service processes}

Clarifying and documenting service processes appears as another essential element in the productising of services as seen through the instances of SP analysed. The relation between service processes and productisation is clear in case of all the instances. Developing and clarifying a company's internal processes and ways of working have been emphasised as an aspect of productisation (A, B, C, D, F, G, $\mathrm{H}, \mathrm{J}$ and $\mathrm{K}$ ): “...developing organisations' internal processes and ways of working is a part of productisation...." Internal customers within an organisation, that is, the people who provide the services, represent a part of the processes involved in productisation and service provision. Hence, it is “...essential to describe processes that most customer cases represent..." and “...special cases can be prepared with separate operating procedures when necessary." (B, H, I and K). A formalised offering and clear processes are seen to reduce instances of overlapping work and increase service quality. The need to clearly describe service processes is emphasised among the SP instances, and there is also a good understanding that some of the processes are visible to customers and some are not (D). The interrelations of activities were seen as important to understand how to improve management and employee understanding.

Describing service processes was seen to benefit the companies by concretising their services, thereby enabling the reproduction of the services and also acting as a source of further ideas (A, C, H, I, K and L): “...experienced as one way to concretise..." and "Describing the process resulted in ideas for further developing and concretising the service." The ability to reproduce the services was emphasised in relation to the fact that more employee knowledge is required (L), whilst productisation was seen to help as it forced a greater focus on service production. Service processes can provide the necessary simplicity and routines for providing services that have a clear and specified form (A, B, I, K and M): “enables a promising specified form and reliability."

Aside from process descriptions, clearly productised services have defined the necessary tools for service provision, including the necessary templates for reporting and the required resources $(\mathrm{C}, \mathrm{H}, \mathrm{K}$ and $\mathrm{M})$ : “...describe the whole service process, including possibly needed tools and service intermediaries. " Some companies seem to utilise very detailed service process descriptions in order to assure an understanding of the service processes, their realisation, the resources involved and the necessary work instructions ( $\mathrm{C}, \mathrm{K}$ and $\mathrm{G})$. Productisation has also been mentioned as being helpful with resource planning.

In some service types, the service processes are defined by an external body; however, there were indications that these definitions were not sufficient to ensure a clear service product, so clearer processes and better descriptions of the ways of working were desired ( $\mathrm{F}$ and $\mathrm{J})$. This may mean that the external body has not adequately considered the service or that only guidelines have been provided. A clear process for service production is seen to be required in order to cope with volume, regardless of the service type.

Service processes are seen as particularly important in relation to the marketing, sales and delivery capability (B, I, L and M): “...service processes, to have a package that is easy to sell and easy to understand and buy..." and “...service delivery will not be a problem...." There were some indications that formalised processes can reduce sales process lead times and the associated costs 
(I), as well as enhancing the lead times of global processes when the required collaborative work is reduced (I). There were also indications that productisation can take place in different parts of the value chain and that it can involve a variety of activities from sales operations to service delivery, including possible implications for the service lifecycle (I and C). Some instances of SP indicated that the service processes are further developed after the initial productisation, while systematic customer feedback was mentioned as one trigger for further development $(\mathrm{C}$ and $\mathrm{H})$.

Finding 3. Clarifying and documenting service processes is an essential part of SP with a specific emphasis on internal clarity for the benefit of management and employees.

\subsubsection{Working methods}

Describing and documenting working methods is seen to involve documenting those service components with linkages to the most suitable working methods in order to enable steady service quality (A, B, D, K and L): “...components... the working methods... most suitable for each phase...” and "...leads to a better quality..." The working methods are portrayed as having linkages to the service processes and blueprints, even to the extent that different phases and working methods can be identified from the blueprint $(\mathrm{C}, \mathrm{H}$ and $\mathrm{M})$. These descriptions and documents enable an understanding of what will be delivered and what the associated benefits are, which enables, for example, the ease of selling and buying ( $\mathrm{L}$ and $\mathrm{M})$.

\subsubsection{Service offering}

Defining services (service offering) and assessing core, supporting and additional services are seen as an important aspect of the productisation of services in all the analysed instances of SP. In order to clarify the services (i.e. the service offering), the necessary service components need to be analysed and defined. This is intended to clarify the core structure of the services so that they do not need to be reinvented every time they are provided $(\mathrm{A}-\mathrm{M})$ : “....services were created, including the service content and the necessary tools and process descriptions, " “...core and additional services...” and "...no need to re-invent for each customer...." Concretising the core services enables the replication of the services and hence makes the service process quicker (C). Analysing the core elements also enables an understanding of which service elements can be considered to be extra (A). Those extra elements can either be supporting elements or additional services (A, B, C, D, E, F, G, H, I, J, K, L and M): “...the convenience of the core service can be enhanced by additional services" and "...which components of the service are essential and which ones could be offered as extras..." Supporting services are mentioned as being particularly useful to distinguish oneself from the competition $(\mathrm{H})$, while additional elements count increasingly towards customer choice (I).

Tailoring services to fulfil particular customer needs becomes possible once it is clear which elements are core, supporting or additional (A, B and C): “...productisation enables profitable tailoring." Tailored elements can then be created more cheaply, which potentially results in better quality and improved customer satisfaction (B). Service definitions contain information about the benefits and value offered to customers, while the descriptions contain information about the individual service elements together with the relevant linkages to the process $(H)$. The resulting united service ensemble can support both internal and external understanding $(\mathrm{C}$ and $\mathrm{H})$ : “...understandable whole, [both] internally and externally," while the defined services enable the addressing of needs at different service levels (J).

Finding 4. Service offerings and the related service product configurations, including the core and additional content, are of essential focus in SP with necessary linkages to corresponding processes. 


\subsubsection{Modularisation of services}

The modularisation of services seems to be relevant to the productisation of services, since most of the data either directly refers to modularisation or makes strong indications towards it (A, B, E, G, H, I, J, $\mathrm{K}, \mathrm{L}$ and $\mathrm{M}$ ), including attempts to break services down into modules (A, E and J): "When productising services, modularisation and replicability cannot be achieved unless there is adequate documentation and guidelines that describe the whole service process, including possibly needed tools and service intermediaries." In a few instances (C, D and F), the data does not directly refer to modularisation, although some additional material that is not included in the analysis does provide indications of modularisation. Some sources already had a very clear modular service structure in place (e.g. G), but they were still developing the structure further.

Manageability was mentioned as one of the motivations behind modularising ( $\mathrm{L}$ and I), while some indicated that altering the set service modules at a later point based on customer requests would not be optimal from the service management perspective (I). Modularising was seen to require an adequate internal understanding of the services ( $\mathrm{L}$ and $\mathrm{M})$. Other named benefits of a modular service structure included support for the pricing of services (A and $\mathrm{H}$ ): "pricing and profit can be influenced via service definitions and by formalising," as well as help in communicating with customers about the services (A) and helping customers to understand what they require of the services. One source indicated that they particularly aim to assess modules during the piloting of services (B).

\subsubsection{Service blueprinting}

Service blueprinting clearly seems to be relevant to the productisation of services. Some of the analysed instances of SP directly discuss service blueprinting by name (C, E, H and L), while in other cases even where it was not named, the concept was clearly understood (A, B, D, F, G, J and K) in terms of how certain service aspects are visible to customers and others are only visible to the company providing the services: "Describing service processes was done with the aid of service blueprint" and "Internal processes are not as visible to the customers." Only in a few instances were these matters either not clear or not discussed (I and M). In addition, one instance (F) seemed to focus more on internal matters, potentially due to the type of service, although their understanding otherwise resembled blueprinting.

Service blueprinting was seen to aid in describing the service processes, enabling clear and detailed descriptions of all relevant activities and participants and separating visible and backstage actions. The service blueprints were also seen to enable a clear understanding of relevant company contacts, as well as emphasising the customers' own role and making a distinction between different service elements. An increased focus on potential pitfalls, problems and details that would likely otherwise be overlooked was also seen to be enabled as a result of blueprinting $(\mathrm{C}, \mathrm{E}, \mathrm{H}$ and L): “...enables seeing critical points in the service process." A similar understanding was visible in several sources (B, G and $\mathrm{K}$ ), while other sources did not contain adequate details beyond the separation between internal activities and those visible to customers (A, D and F). Additionally, the definition of the customer's responsibilities and those of the organisation providing the services were seen as distinct as a result of blueprinting (B). There were indications that the working methods and different service phases would be easier to identify as a result of blueprinting, as would the discovery of new service modules ( $\mathrm{H}$ and L). One company had even been mapping its customers' processes and the contact employees' actions (L). Blueprinting was also said to support the standardisation and communication of service delivery processes (L). 


\subsubsection{Customer benefits}

SP seems to involve the assessment of customer benefit. The companies' customer orientation already indicated that customer benefit should be clarified prior to productisation. The data show that some companies have tried to clarify the customer benefit via prior questionnaires and customer feedback on other services or based on prior experience of providing certain service elements (B, C, E and F). In some instances, the need for the services and the potential customer benefit were already known or specified, although the sources did not reveal how this was clarified (D, G, J and M). In a few instances, the customer benefits were not directly discussed (H and I), whereas in other instances, the customers could not fully perceive all the service benefits, although productisation was expected to provide clarity ( $\mathrm{K}$ and $\mathrm{L})$. The systematic follow-up of services and the evaluation of services after their provision were also mentioned as means of clarifying the customer benefit and further developing the services (A, C and M). In certain types of services, the customer benefit may be influenced by considerations of who the customers are, since the service user may be different from the party paying for the service, or else the service definition impacts considerations of who the customer is and whether the customer and the service user are different (E and $G$ ).

\subsubsection{Market potential, volumes and competition}

There were some indications that the market potential, possible volumes and competition might be analysed as part of productisation; however, none of the analysed instances of activities related to the productising of services directly discussed these matters. In only two instances (B and D) was the market potential analysed during productisation, while in most instances the market potential was not directly discussed (A, C, E, F, G, H, I, J, K, L and M). In a similar fashion, there were indications that volumes might be analysed ( $\mathrm{D}$ and $\mathrm{J}$ ), although this was not discussed thoroughly. In most instances, the volumes were either not analysed or it was unclear whether they were analysed (A, B, C, E, F, G, H, I, K, L and $\mathrm{M})$. In addition, two instances featured indications that competition was analysed (B and D), but this was mostly not directly discussed (A, C, E, F, G, H, I, K, L and M).

\subsubsection{Piloting productised services}

The piloting of the productised services was evident in a few sources (B, H, L and M), while two also mentioned follow-up and feedback with a similar purpose (C and D). In some cases (C, D and K), the data did not address piloting, although some additional material that is not included in the analysis did provide relevant indications. The purpose of piloting services in real customer environments was to obtain feedback before including the service in the company portfolio. Piloting was seen to allow the testing of the services and the confirmation of the associated success potential. Pilots were seen to be possible when companies have a pre-existing relationship with customers. There were also indications that piloting enabled the use of internal working methods and learning about the service ( $\mathrm{L}$ and $\mathrm{M})$. It was also noted that any flaws in the service can be addressed during the service encounter, which is not true in the case of a physical product that is produced beforehand. Hence, any feedback on services is also seen as being valuable during the service provision.

Finding 5. The practices and techniques that are inherent to SP each focus on supporting replicability and structure, aiding in describing service processes, identifying interfaces, understanding customer benefits, gaining feedback and potentially others. 


\subsection{SP Elements Synthesised}

Table 5 summarises the findings concerning the elements of service productisation together with the support provided by the previous literature. The potential SP elements are presented in conjunction with the 13 analysed instances of SP, which serves to indicate whether each instance either provides support (S) or partial support (P) for each of the findings, as well as whether certain findings are not supported $(\mathrm{N})$ by some instances. The table also indicates if no relevant evidence is found (-) in certain instances. The support or partial support found in the existing literature has been indicated. However, the potential hierarchy of the findings is ignored in the table. 
Table 5. Findings — elements of service productisation

\begin{tabular}{|c|c|c|c|c|c|c|c|c|c|c|c|c|c|c|}
\hline \multirow{2}{*}{ Findings } & \multicolumn{13}{|c|}{ Instance of SP } & \multirow{2}{*}{ Literature } \\
\hline & $\mathbf{A}$ & B & $\mathbf{C}$ & $\mathbf{D}$ & $\mathbf{E}$ & $\mathbf{F}$ & $\mathbf{G}$ & $\mathbf{H}$ & $\mathbf{I}$ & $\mathbf{J}$ & $\mathbf{K}$ & $\mathbf{L}$ & $\mathbf{M}$ & \\
\hline $\begin{array}{l}\text { Customer orientation is relevant } \\
\text { to SP. }\end{array}$ & $\mathrm{S}$ & $\mathrm{S}$ & $\mathrm{S}$ & $\mathrm{S}$ & $\mathrm{P}$ & $\mathrm{P}$ & $\mathrm{P}$ & $\mathrm{S}$ & $\mathrm{P}$ & $\mathrm{P}$ & $\mathrm{S}$ & $\mathrm{S}$ & $\mathrm{S}$ & $\begin{array}{l}\text { Supported by: Aapaoja et al. 2012; Artto et al. 2008; Danson et al. 2005; Deshpande et al. } \\
\text { 1993; Drucker 1954; Flamholtz 1995; Harkonen et al. 2015; Nagy 2013; Rajahonka 2013; } \\
\text { Suominen et al. 2009; Simula et al. } 2008 \\
\text { Partially supported by: Alam and Perry 2002; Slater et al. 2010; Newman et al. 2016; Wang } \\
\text { et al. } 2016\end{array}$ \\
\hline $\begin{array}{l}\text { Clarifying and documenting } \\
\text { service processes is an essential } \\
\text { part of SP. }\end{array}$ & $\mathrm{S}$ & $\mathrm{S}$ & $\mathrm{S}$ & $\mathrm{S}$ & $\mathrm{S}$ & $\mathrm{S}$ & $\mathrm{S}$ & $\mathrm{S}$ & $\mathrm{S}$ & $\mathrm{S}$ & $\mathrm{S}$ & $\mathrm{S}$ & $\mathrm{S}$ & $\begin{array}{l}\text { Supported by: Aapaoja et al. 2012; Andreini et al. 2015; Bitner et al. 2008; Carlborg and } \\
\text { Kindström 2014; Chattopadhyay 2012; Edvardsson and Olson 1996; Fließ and Kleinaltenkamp } \\
\text { 2004; Grönroos 2008; Harkonen et al. 2015; Jaakkola 2011; Kingman-Brundage et al. 1995; } \\
\text { Lehtonen et al. 2015; Prilla et al. 2012; Rajahonka 2013; Ritala et al. 2013; Shostack 1984; } \\
\text { Silvestro 1999; Suominen et al. 2009; Ukko et al. 2011; Valminen and Toivonen 2012; }\end{array}$ \\
\hline $\begin{array}{l}\text { Describing and documenting } \\
\text { working methods is relevant to } \\
\text { SP. }\end{array}$ & $\mathrm{S}$ & $\mathrm{P}$ & $\mathrm{P}$ & $\mathrm{S}$ & - & $\mathrm{P}$ & - & $\mathrm{S}$ & - & $\mathrm{P}$ & $\mathrm{S}$ & $\mathrm{P}$ & $\mathrm{P}$ & Supported by: Bettiol et al. 2012 \\
\hline $\begin{array}{l}\text { Defining the service offering, } \\
\text { including core-, supporting- and } \\
\text { additional elements is an } \\
\text { essential part of SP. }\end{array}$ & $\mathrm{S}$ & $\mathrm{S}$ & $\mathrm{S}$ & $\mathrm{S}$ & $\mathrm{S}$ & $\mathrm{S}$ & $\mathrm{S}$ & $\mathrm{S}$ & $\mathrm{S}$ & $\mathrm{S}$ & $\mathrm{S}$ & $\mathrm{S}$ & $\mathrm{S}$ & $\begin{array}{l}\text { Supported by: Aapaoja et al. 2012; Baltacioglu et al. 2007; Chattopadhyay 2012; Cowell 1988; } \\
\text { Edvardsson 1997; Edvardsson and Olsson 1996; Flamholtz 1995; Grönroos 1982; Grönroos et al. } \\
\text { 2000; Harkonen et al. 2015; Hemple et al. 2015; Jaakkola 2011; Johne and Storey 1998; Lehtonen } \\
\text { et al. 2015; Leon and Davies 2008; Lukka and Partanen 2014; Nagy 2013; Rajahonka 2013; Roos } \\
\text { and Edvardsson 2008; Saarela et al. 2013; Simula et al. 2008; Ukko et al. 2011; Valminen and } \\
\text { Toivonen 2012; Valtakoski and Järvi 2016; Wang } 2011\end{array}$ \\
\hline $\begin{array}{l}\text { Modularisation of services is } \\
\text { relevant to SP. }\end{array}$ & $\mathrm{S}$ & $\mathrm{S}$ & $\mathrm{P}$ & $\mathrm{P}$ & $\mathrm{S}$ & $\mathrm{P}$ & $\mathrm{S}$ & $\mathrm{S}$ & $\mathrm{S}$ & $\mathrm{S}$ & $\mathrm{S}$ & $\mathrm{S}$ & $\mathrm{S}$ & $\begin{array}{l}\text { Supported by: Leon and Davies 2008; Nagy 2013; Rajahonka 2013; Ritala et al. 2013; Valminen } \\
\text { and Toivonen, } 2012\end{array}$ \\
\hline $\begin{array}{l}\text { Service blueprinting is a } \\
\text { relevant practice for SP. }\end{array}$ & $S$ & $\mathrm{~S}$ & $\mathrm{~S}$ & $\mathrm{~S}$ & $\mathrm{~S}$ & $S$ & $\mathrm{~S}$ & $\mathrm{~S}$ & $\mathrm{~S}$ & $\mathrm{~S}$ & $\mathrm{~S}$ & - & - & $\begin{array}{l}\text { Supported by: Valtakoski and Järvi } 2016 \\
\text { Partially supported by: Valminen and Toivonen } 2012\end{array}$ \\
\hline $\begin{array}{l}\text { Assessing customer benefit } \\
\text { prior to/after productisation is } \\
\text { relevant to SP. }\end{array}$ & $S$ & $\mathrm{~S}$ & $\mathrm{~S}$ & $\mathrm{~S}$ & $\mathrm{~S}$ & $S$ & $\mathrm{P}$ & $\mathrm{N}$ & $\mathrm{N}$ & $\mathrm{P}$ & $\mathrm{S}$ & $\mathrm{S}$ & $\mathrm{P}$ & $\begin{array}{l}\text { Supported by: Danson et al. 2005; Flamholtz 1995; Flamholtz and Aksehirli 2000; Flamholtz } \\
\text { 2002; Flamholtz and Hua 2002; Flamholtz and Hua 2003; Flamholtz and Kurland 2005; Harkonen } \\
\text { et al. 2015; Rajahonka } 2013 \\
\text { Partially supported by: Artto et al. 2008; Simula et al. 2008; Suominen et al. } 2009\end{array}$ \\
\hline $\begin{array}{l}\text { Analysing market potential may } \\
\text { or may not be relevant to SP. }\end{array}$ & - & $\mathrm{S}$ & $\mathrm{S}$ & - & - & - & - & - & - & - & - & - & - & - \\
\hline $\begin{array}{l}\text { Analysing volumes may or may } \\
\text { not be relevant to SP. }\end{array}$ & - & - & - & $\mathrm{S}$ & - & - & - & - & - & $\mathrm{S}$ & - & - & - & - \\
\hline $\begin{array}{l}\text { Analysing competition may or } \\
\text { may not be relevant to SP. }\end{array}$ & - & $\mathrm{S}$ & - & $\mathrm{S}$ & - & - & - & - & - & - & - & - & - & - \\
\hline $\begin{array}{l}\text { Piloting is potentially an } \\
\text { essential practice for SP. }\end{array}$ & - & $\mathrm{S}$ & $S$ & $\mathrm{~S}$ & - & - & - & $S$ & - & - & $\mathrm{S}$ & $S$ & $\mathrm{~S}$ & Partially supported by: Valtakoski and Järvi 2016 \\
\hline
\end{tabular}

$(-)=$ No relevant evidence found 
The nature of SP is further illustrated in Figure 1. Successful service productisation results in a systematised, tangibilised, and formalised offering as also indicated by finding 1 . The empirical analysis indicates that the main focus of SP is on the service product and the service processes, and it is in line with the literature findings. The service product breaks down into service elements, including core, supporting and additional elements. The empirical findings show customer orientation as relevant for SP, indicating customer centricity, serving to provide customer benefits. Practices and techniques, including blueprinting, modularisation, working methods and customer benefit assessments, are indicated as relevant for SP, and there may be others. The literature-based assertions presented are evidenced in the analysed instances of SP to some degree. In addition to the description above, there are indications that SP can be innovative and developmental in nature.

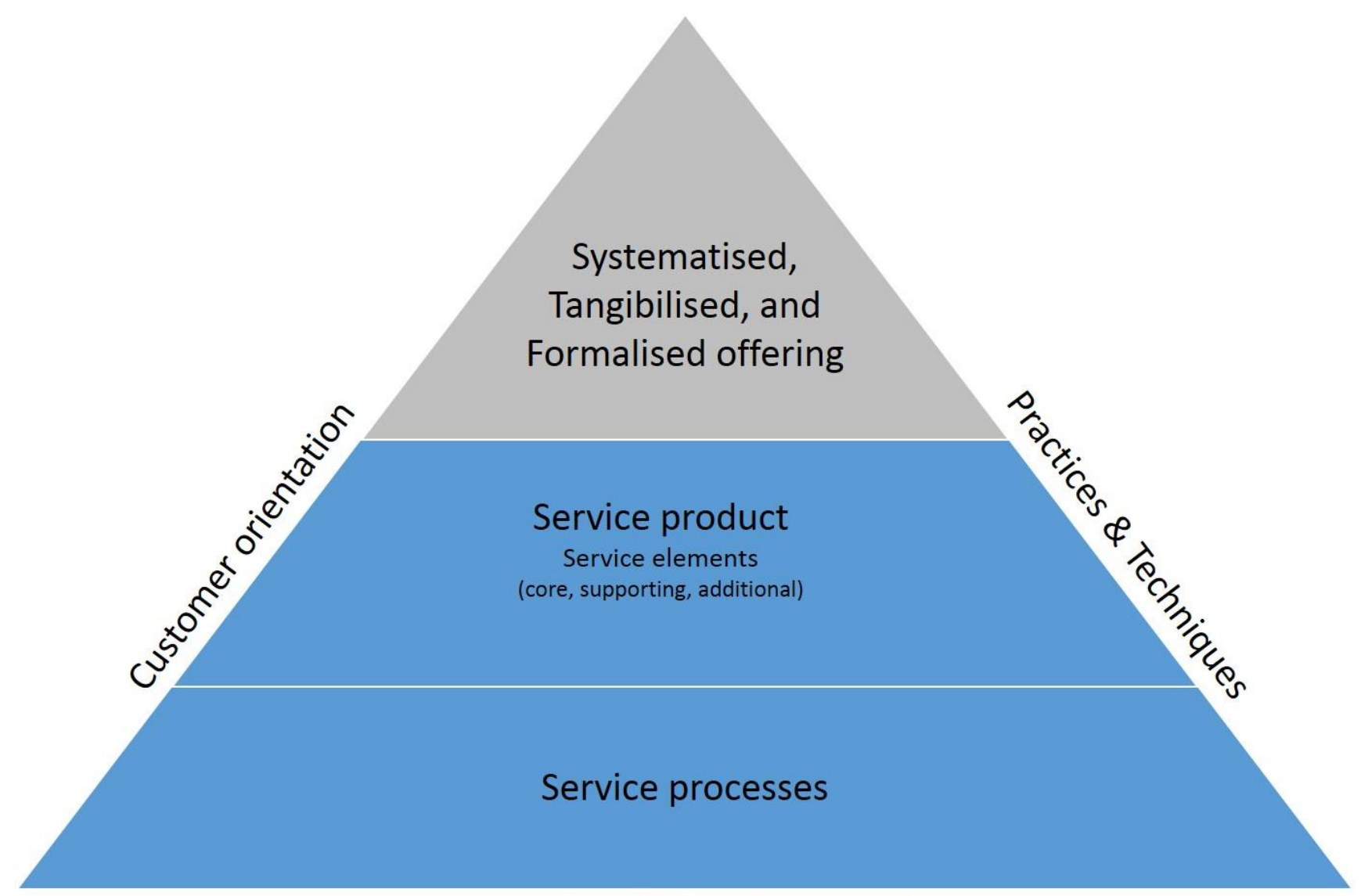

Innovative \& developmental

Figure 1. The nature of service productisation

Figure 2 illustrates a typology of SP in the context of commercial and technical service product portfolios by linking all the identified elements of SP to a relevant context. Figure 2 links and further distils the findings, the content of Tables 4 and 5 and Figure 1. The frame of thinking in terms of commercial and technical service product portfolios is adopted from Tolonen (2016), which mainly addressed physical products. 


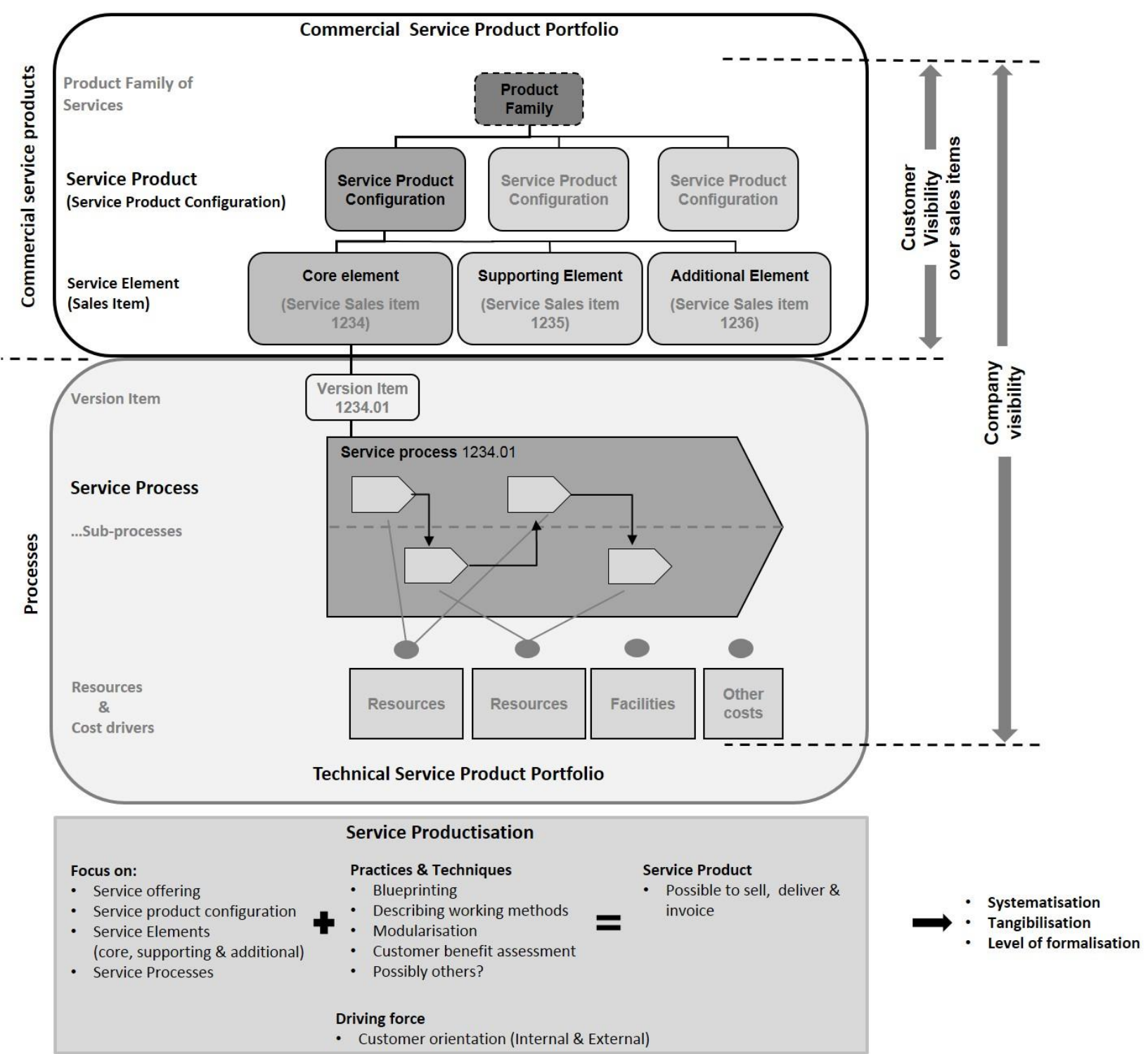

Figure 2. Typology of service productisation in the context of commercial and technical service product portfolios

A company's commercial service portfolio contains all its commercial service products. A company can, for example, have an entire product family of services containing service products that can be sold to customers. The service products are all service product configurations consisting of different service elements or sales items. These sales items have known costs and they can be priced and sold as either part of a service product configuration or separately. Customers typically only have visibility over the commercial service product portfolio.

A technical service product portfolio consists of service processes, sub-processes and the required resources, which can be people skills and/or materials (e.g. necessary facilities). Both the commercial and the technical service portfolio are visible to the company. Viewing services in this manner allows the consideration of perspectives concerning both the commercial and the technical side of things. The technical side of the service product portfolio might be better known by the teams handling service development, engineering, service provision, service testing, purchasing, logistics as well as by the suppliers. The commercial service products, however, might be more familiar to teams working in marketing and sales, service product management and with customers. The overall services become more manageable as the technical relations between the services are 
easier to maintain when those services are modelled through sellable and technical structure levels. Since service tasks can be undertaken by customers, their level of visibility may vary.

Service productisation particularly focuses on the offering and the service processes, which impacts both the commercial and the technical side. Defining the service offering is an essential part of SP and it covers the service product configurations as well as the service elements and the sales items, including the core, supporting and additional elements. Clarifying and documenting the service processes, including any sub-processes, are also essential for SP. The interrelation of the service processes and the related sub-processes is modelled together with the relevant linkages to required resources, people skills, materials, facilities and so on.

Service productisation may involve different practices and techniques, including blueprinting, describing working methods, modularisation and customer benefit assessment. Service blueprinting is a customer-oriented methodology that supports describing of service processes, and it is a relevant practice for service productisation. Describing and documenting working methods also seems relevant to SP, although it is not necessarily a suitable practice. Describing working methods provides a task orientation that can either be inherent to the documented service processes or seen as a supporting practice. The modularisation of services, however, is more commonly relevant to SP, and it is particularly useful when considering services available through commercial and technical service portfolios. Modularisation clarifies services and helps to determine their structure, including the service processes. Modularisation is particularly useful in creating replicability as well as enabling re-use and variation and addressing complexity. Modularity should, however, be seen as a characteristic of the technical service product portfolio, where version items are obtained cost effectively as a result of technical items and processes via modularisation. In comparison, configurability is a characteristic of the commercial service product portfolio, where service product configurations are formed from sales items. Additionally, a customer benefit assessment prior to or after productisation may be relevant for SP in terms of better understanding the customer perspective on services. Another technique that can be utilised to obtain the customer perspective involves piloting services, which may be used to test services and serve as a feedback mechanism. In addition, other practices and techniques may be used for the benefit of SP, although the evidence to date is rather scarce in this regard.

Customer orientation is an important driving force behind SP. It includes both internal and external customers, since involving customers is vital for successful productisation. Customer orientation can imply utilising different methods and various relevant practices, although it can also be a mode of thinking during all activities. Customer orientation is particularly relevant to SP and it can hence be seen as a driving force behind SP activities.

Successful productisation results in a service product that can be sold, delivered and invoiced. A company can have a number of service products that form a product family of services. Productisation also leads to the systematising and tangibilising of the service offering and related processes, while creating a level of formalisation. Formalisation in this context may entail the standardisation of service components and processes.

Systematisation is important for services because it influences the ability to re-produce the services. Systematisation takes place via the modularisation of the service offering and the associated processes. In particular, clearly describing and modelling the service and the processes promotes systematisation. It is the systematisation of internal processes that notably takes place during productisation. The line of visibility has significance, while service blueprinting can be useful for describing the processes, which is a methodology relevant to SP. Additionally, it is the 
creation of routines that contributes the most to systematisation. Clarifying the service offering and utilising service product configurations to include the core, supporting and additional elements conveys systematisation. Various techniques may be utilised and may result in systematisation, whereas systematisation also links to customer orientation.

Tangibilisation is vital for service businesses, since it relates to how well services and service processes are understood, both internally and externally. The customer orientation indirectly indicates tangibilisation through the involvement of internal and external customers. It is, however, a clear and structured service offering that best supports a service in becoming tangible. Defining and describing service processes also plays a role in concretising services and making them more tangible. Creating basic structures and processes supports tangibility. Additionally, it is the process modularity that best supports tangibility. Further, tangibility can be increased by means of modularity when the rules for combining services are too complex for customers and employees to understand. Moreover, the structural understanding and the understanding of customer-specific activities, resources and competencies support tangibility, and they can be achieved via methods such as blueprinting. Understanding the interrelations of activities hence improves management and employee understanding and supports tangibility for customers.

The level of formalisation can make a service more manageable for a company internally and provide some other benefits while still allowing for different service product configurations in order to meet various needs. This does not exclude the standardisation of service elements or processes but rather allows for different degrees of formalisation. Formalising the offering and instituting clear processes may reduce overlapping work and increase the service quality. Aside from formalised processes, a structured and clear offering is also relevant for formalisation. Although, in relation to service offerings, processes and methods, the term "standardisation" tends to be used, the true aim is in fact to achieve a degree of formalisation rather than complete standardisation. The nature of the service and the business environment may influence the necessary degree of formalisation. The level of formalisation may, however, go beyond merely clarifying and documenting. Indeed, formalisation may appear in the form of creating replicability, well-defined processes, routines and descriptions of activities. In addition, modularity is linked to formalisation, and it can help in making the service characteristics explicit. The product-like nature of a productised service is the result of a certain level of formalisation.

Finding 6. Managing and perceiving service offerings and processes in a structured enough manner in the context of SP, to enable understanding of services both internally and externally, is a prerequisite for the effective ability to sell, deliver and invoice services and contribute towards business performance. Service complexity and the size of the service portfolio may emphasise this prerequisite.

\section{Discussion}

This study helps enhance the understanding of SP by bringing together past relevant journal discussions and by synthesising previously discrete elements into an ensemble of categories - a conceptual typology - for SP. This study identifies elements of SP and makes a clear contribution to practice and service literature. The created typology supports the understanding of what is considered as SP, both through the identified elements of SP and by presenting the elements in the context of commercial and technical service product portfolios to provide further clarity. The proposed typology is relevant for service product management to model services and to support effective service management. The study clarifies the role of SP in relation to systematising and 
tangibilising the service offering and the related processes as well as in the creation of a suitable level of formalisation.

\section{Technical Implications}

In terms of technical Implications of this study, it supports the systematic approaches to services applied by Edvardsson (1997) and Valminen and Toivonen (2012) in terms of emphasising the importance of systematisation. This study also makes a contribution by highlighting the importance of certain structures to the possibility of selling, delivering and invoicing as the underlying motivation for SP. New contributions are also made in line with Harkonen et al. (2015) by showing how SP is potentially a specific concept that aims to address the service offering, including the structure and service processes, as well as to understand and link to the necessary resources. This is a pragmatic perspective that is in accordance with the division of services into important service components presented by Edvardsson (1997) that emphasises service prerequisites.

\section{Theoretical Implications}

This study brings new perspectives to the service discussion, and it links together the previously rather dispersed discussion on SP by introducing a typology to provide a clearer context for the discussion. Considering SP systematically and viewing the commercial and technical sides can be seen to support resource planning and reduce the dependency on individual employees, which potentially allows for the more appropriate use of experienced people. This extends the work of Jaakkola (2011) and Chattopadhyay (2012) by providing a pragmatic context to SP considerations. The systematic approach, however, does not mean that the division of services into service components needs to be static, since customers' needs and valuations vary. This is in line with the work by Roos and Edvardsson (2008) and Johne and Storey (2008). SP provides a context for addressing the changing needs in a manner that services will remain manageable.

The focus on the offering and particularly on the internal processes has been emphasised to support situations where the same service is ordered multiple times. It serves to reduce costs and avoid ad hoc work. This is in line with the findings of Nagy (2013), according to which SP forces focus on more productive activities, supporting stable service quality and coping with volumes. Simultaneously, SP acknowledges that customers require an understanding of what will be delivered and what the associated benefits are, although they do not necessarily need a detailed understanding of the service composition. Contrary to claims that productisation results in itemisation and less valuable solutions for customers (Hellström et al., 2016), the aim of SP is to attain more manageable value. Additionally, in line with Andreini et al. (2015), a key to avoiding customers perceiving productised services in a negative way is a focus on customer interaction and ensuring the adequate consideration of how customers feel their needs and expectations are being met.

Various practices and techniques are inherent to SP, which this study presents as elements of SP in conjunction with the focus of SP on offering and processes. This study hence confirms that SP applies various techniques and is in line with the work by Valtakoski and Järvi (2016). New contribution is made by attempting to name the previously vague practices and techniques. This study provides support for Valminen and Toivonen (2012) and Valtakoski and Järvi (2016) on the previously limited discussion on blueprinting in the context of SP by presenting evidence of the analysed instances of SP. This study also supports Rahikka et al. (2011) and Bask (2010) on the 
topic of modularisation supporting SP in providing means of addressing services internally, while supporting the manageability of complex services. The relevance of assessing the customer benefit is also supported in line with several studies (Danson et al., 2005; Flamholtz, 1995; Flamholtz and Aksehirli, 2000; Flamholtz and Kurland, 2005; Harkonen et al., 2015; Rajahonka, 2013) to provide a feedback loop and link to perceived value and customer perceptions. Practices such as piloting may also be relevant to act as a potential feedback mechanism for confirming the success of productised services and to learn about the service. Working methods, however, have not been directly discussed in the context of SP before. This study supports previous literature on the relevance of customer orientation in SP and further emphasises its significance for the internal and external need aspects.

The consideration of the commercial and technical side of things can be seen as beneficial if perceiving SP through commercial and technical service portfolios, since this aids in understanding why the productisation discussion has previously appeared in a variety of forums. Presenting SP through commercial and technical service product portfolios is new to service literature, although this type of categorisation has previously been considered for physical products by Tolonen (2016). By analysing both the commercial and technical sides of services, it is possible to achieve a better understanding of how SP relates to service development, service design, commercialisation, operations, service sales and marketing.

\section{Managerial implications}

The managerial implications of this study include the provision of an improved context for considering SP. Managers can particularly benefit from the support offered by SP in achieving internal manageability and control over services. It is vital for companies to control what is delivered and when it will be delivered in order to steer and manage services. Service productisation supports the creation of the necessary structures to achieve this. Additionally, the potential of using commercial and technical portfolios to reflect on the commercial and technical sides of services supports service lifecycle considerations as well as those of the service structure layers along with supporting the understanding of SP. Managers can better understand the role of commercial service offerings and technical service processes in the commercial and technical contexts, while also comprehending the practices and techniques relevant to SP. This context may even help to determine where the service configuration and modularisation take place structurally. Service productisation also helps managers understand how service products are composed beyond a regular blueprint and how each sales item is inherently linked to corresponding processes and sub-processes. The importance of customer orientation as the underlying force behind SP supports the awareness of the need aspect of SP.

Service productisation aids in and promotes the systematising, tangibilising and formalising of services. Systematisation has an impact on the ability to reproduce the services and it can take place, for example, via configuring the offering and modularising the associated processes. Tangibilisation is particularly relevant for service businesses, since it relates to how well the offering and service processes are understood, both internally and externally. A level of formalisation, perhaps even standardisation, can make the service more manageable internally, while still allowing for various needs to be met. Companies can benefit from the positive effects of SP in terms of achieving systematic and tangible services that are formalised to a degree relevant to the particular company, while practitioners can clearly benefit from any improvements in the manageability of services. Additionally, the earning logic and communication will only be clear if 
the services are well perceived and adequate operational clarity exists. SP can provide further benefits by promoting the manageable and cost-effective tailoring of services to meet customer needs as well as supporting the clarification of the role of customer interaction in relation to service content and structure and meeting customer expectations. Managers can undoubtedly benefit from increased clarity regarding what actually counts as SP. This is important because although productisation is often discussed among practitioners, it has historically lacked adequate academic support. This study may also provide benefits in terms of providing a context that supports the perception of SP among service development, service design, service marketing and sales, among other activities.

\section{Limitations and future research}

The limitations of this study include the potentially limited view of focusing on SP primarily based on previous journals that address the concept by name and by analysing the content, which could potentially result in relevant discussions being overlooked. The study uses practical evidence by analysing instances of SP that promote the concept, although it does consist of secondary data that has its limitations. The utilised data were collected for the purposes of prior studies, for unpublished university theses, rendering it non-symmetrical in some respects. Further, the focus of this study has not been on the primary intent behind the original data. Applying inductive logic to the instances of SP by using secondary data has its limitations. The data, however, are likely to be less biased with regards to the aims of this study. Applying an inductive approach to qualitative data is not the strongest approach for either theory or model development. Also, shaping the findings without the possibility of applying statistical tests results in limitations. Even the presentation style used may have its limitations while working on a topic involving previous discussions of a rather dispersed nature. The capabilities of the researchers may also pose a limitation in terms of the likelihood of incorrect interpretations; however, several people have confirmed the findings, which makes this less likely, together with the number of sources helping to reduce the significance of individual ones.

Future research could aim to verify the findings of this study by using primary data, particularly with a focus on SP. Additionally, future studies are needed to bring further clarity to the currently lesser known considerations of SP from the service structure or decomposition logic perspectives that hinder the true possibilities for effective service product portfolio management both horizontally and vertically. This type of approach would include service lifecycle considerations and further analysing the service structure layers. The lifecycle here should focus on service requirement management, service specification, service concept design, service prototyping, service piloting, service implementation, service usage and service obsolescence. Hence, the discussion of services by means of commercial and technical service product portfolios will need to be elaborated further with regards to the division between the commercial and technical sides of the service. Additionally, considering SP in the context of different types of service structure considerations might prove beneficial. Service productisation in relation to responsibilities/ownership issues also requires further clarification. Further studies are required to promote the understanding of how SP affects the service delivery system. The role of SP needs to be further analysed in the context of individual service functions in terms of elaborating how SP links to, or differs from, the regular activities. In addition, studies are needed to further clarify the relation between SP and relationship-based activities. The impact of different service types on SP might also be an interesting topic for further study. 


\section{References}

Aapaoja, A., Kujala, J., and Pesonen, L.T.T. (2012), “Productization of University Services”, International Journal of Synergy and Research, Vol. 1, No. 1, pp. 89-106.

Alam, I. and Perry, A. (2002) "A customer-oriented new service development process", Journal of Services Marketing, Vol. 16, No. 6, pp. 515-534.

Andreassen, T.W., Kristensson, P., Lervik-Olsen, L., Parasuraman, A., McColl-Kennedy, J.R., Edvardsson, B., and Colurcio, M. (2016) "Linking service design to value creation and service research", Journal of Service Management, Vol. 27, No. 1, pp.21 $-29$

Andreini, D., Salo, J., Wendelin, R., Pezzotta, G. and Gaiardelli, P. (2015) "From a service-dominant logic to a good-dominant logic: Consequences for the buyer-seller relationships of a corporate bank", IMP Journal, Vol. 9, No. 3, pp.250-266.

Anupam, V., Hull, R.B., Kanwal, S.S., Kumar, B. (2006) "An introduction to lucent's service enhancement layer", Bell Labs Technical Journal, Vol. 10, No. 4, pp.179-196.

Aravirta, H. (2010) "Developing a customer-oriented approach for suite service", Laurea University of Applied Science, Espoo, Finland. pp. 54. <Available online> http://www.theseus.fi/handle/10024/15643

Ardley and Quinn (2014) "Practitioner accounts and knowledge production An analysis of three marketing discourses", Marketing Theory, Vol. 14, No. 1, pp.97-118.

Arora, A., Arunachalam, V.S., Asundi, J. and Fernandes, R. (2001) "The Indian software services industry", Research Policy, Vol. 30, No. 8, pp.1267-1287.

Baltacioglu, T., Ada, E., Kaplan, M.D., Yurt O. and Kaplan, Y.C. (2007) "A New Framework for Service Supply Chains", The Service Industries Journal, Vol. 27, No. 2, pp. 105-124

Bask, A., Lipponen, M., Rajahonka, M. and Tinnilä, M. (2010) "The concept of modularity: diffusion from manufacturing to serv ice production", Journal of Manufacturing Technology Management, Vol. 21, No. 3, pp.355-375.

Bask, A.H., Tinnilä, M. and Rajahonka, M. (2010b) "Matching service strategies, business models and modular business processes", Business Process Management Journal, Vol. 16, No. 1, pp. 153-180.

Bask, A., Lipponen, M., Rajahonka, M., Tinnilä, M., (2011)"Framework for modularity and customization: service perspective”, Journal of Business \& Industrial Marketing, Vol. 26, No. 5, pp.306-319.

Bebko, C.P. (2000) "Service intangibility and its impact on consumer expectations of service quality", Journal of Services Marketing, Vol. 14, No. 1, pp. 9-26.

Bettiol, M., Di Maria, E. and Grandinetti, R. (2012) "Codification and creativity: knowledge management strategies in KIBS", Journal of Knowledge Management, Vol. 16, No. 4, pp. 550-562.

Bitner, M.J., Ostrom, A.L. and Morgan, F.N. (2008) "Service Blueprinting: A Practical Technique for Service Innovation", California Management Review, Vol. 50, No. 3, pp. 66-94.

Böttcher, M. and Klingner, S. (2011) "Providing a method for composing modular B2B services", Journal of Business \& Industrial Marketing, Vol. 26, No. 5, pp.320-331.

Böttcher, M. and Fähnrich, K-P. (2011) "Service Systems Modeling: Concepts, Formalized Meta-Model and Technical Concretion", The Science of Service Systems, in the series Service Science: Research and Innovations in the Service Economy, pp 131-149.

Carlborg, P. and Kindström, D. (2014) "Service process modularization and modular strategies", Journal of Business \& Industrial Marketing, Vol. 29, No. 4, pp. 313-323.

Chattopadhyay, N. (2012), "Productisation of Service: A Case Study", International Journal of Advanced Computer Science and Applications, Vol. 3, No. 12, pp. 197-201.

Cowell, D.W. (1988), "New service development”, Journal of Marketing Management, Vol. 3 No. 3, pp. $296-312$.

Cowton, C.J. (1988) "The Use of Secondary Data in Business Ethics Research", Journal of Business Ethics, Vol. 17, No. 4, pp 423434.

Cusumano, M.A. (2008) "The Changing Software Business: Moving from Products to Services", IEEE Computer, Vol. 41, No. 1, pp.20-27.

Danson, M., Helinska-Hughes, E., Hughes, M., and Whittam, G. (2005) "National and local agency support for Scottish SME internationalisation activity: lessons for small transition economies", International Journal of Entrepreneurship and Small Business, Vol. 2, No. 4, pp. 312-330.

de Brentani, U. (2001) "Innovative versus incremental new business services: different keys for achieving success", Journal of Product Innovation Management, Vol. 18, No. 3, pp. 169-187.

den Hertog, P., van der Aa, W., and de Jong, M.W. (2010) "Capabilities for managing service innovation: towards a conceptual framework", Journal of Service Management, Vol. 21, No. 4, pp.490-514.

Deshpande, R., Farley, J.U. and Webster, F.E. (1993), "Corporate culture, customer orientation, and innovativeness in Japanese firms: a quadrad analysis, Journal of Marketing, Vol. 57, No. 1, pp. 23-37.

Djellal, F., Gallouj, F. and Miles, I. (2013) "Two decades of research on innovation in services: Whichplace for public services?", Structural Change and Economic Dynamics, Vol. 27, pp. 98-117.

Docters, R., Reopel, M., Sun, J-M. and Tanny, S. (2004) 'Capturing the unique value of services: why pricing of services is different', Journal of Business Strategy, Vol. 25, No. 2, pp.23-28.

Drucker, P.F. (1954) “The Practice of Management”, Harper \& Row, New York, NY. 
Dörner, N., Gassmann, O. and Gebauer, H. (2011) "Service innovation: why is it so difficult to accomplish?", Journal of Business Strategy, Vol. 32, No. 3, pp. 37-46.

Edvardsson, B. and Olsson, J. (1996) "Key Concepts for New Service Development", The Service Industries Journal, Vol. 16, No. 2, pp. $140-164$.

Edvardsson, B. (1997) "Quality in new service development: Key concepts and a frame of reference", International Journal of Production Economics, Vol. 52, No. 1-2, pp. 31-46.

Edvardsson, B. (2005) "Service quality: beyond cognitive assessment", Managing Service Quality: An International Journal, Vol. 15, No. 2, pp. 127-131.

Edvardsson, B., Gustafsson, A. and Roos, I. (2005) "Service portraits in service research: a critical review", International Journal of Service Industry Management, Vol. 16, No. 1, pp. 107-121.

Edvardsson, B., Meiren, T., Schäfer, A., Witell, L. (2013) "Having a strategy for new service development - does it really matter?", Journal of Service Management, Vol. 24, No.1, pp.25-44.

Eisenhardt, K.M. (1989) "Building Theories from Case Study Research", The Academy of Management Review, Vol. 14, No. 4, pp. $532-550$.

Eissens-van der Laan, M., Broekhuis, M., Van Offenbeek, M. and Ahaus, K. (2016) "Service decomposition: a conceptual analysis of modularizing services", International Journal of Operations \& Production Management, Vol. 36, No. 3, pp.308-331.

Fink, A. (2004) “Conducting Research Literature Reviews: From the Internet to Paper”, (2nd edition), Sage Publications, Thous and Oaks, CA, USA.Flamholtz, E. (1995), "Managing organizational transitions: Implications for corporate and human resource management”, European Management Journal, Vol. 13, No. 1, pp. 39-51.

Flamholtz, E.G., and Aksehirli, Z. (2000), "Organizational success and failure: an empirical test of a holistic model”, European Management Journal, Vol. 18, No. 5, pp. 488-498.

Flamholtz, E., and Hua, W. (2002), "Strategic Organizational Development and the Bottom Line: Further Empirical Evidence", European Management Journal, Vol. 20, No. 1, pp. 72-81.

Flamholtz, E.G. (2002), "Towards an integrative theory of organizational success and failure: previous research and future is sues", International Journal of Entrepreneurship Education, Vol. 1, No. 3, pp. 297-320.

Flamholtz, E., and Hua, W. (2003), "Searching for Competitive Advantage in the Black Box", European Management Journal, Vol. 21, No. 2, pp. 222-236.

Flamholtz, E.G. (2005), "Strategic Organizational Development, Infrastructure, and Financial Performance: An Empirical Investigation", International Journal of Entrepreneurship Education, Vol. 3, No. 2, pp. 117-142.

Fließ, S. and Kleinaltenkamp, M. (2004) "Blueprinting the service company: Managing service processes efficiently", Journal of Business Research, Vol. 57, No. 4, pp. 392-404.

Gladstone, B.M., Volpe, T., Boydell, K.M. (2007) "Issues Encountered in a Qualitative Secondary Analysis of Help-Seeking in the Prodrome to Psychosis", Journal of Behavioral Health Services \& Research, Vol. 34, No. 4, pp 431-442.

Goldstein, S.M. Johnston, R., Duffy, A. and Rao, J. (2002) "The service concept: the missing link in service design research?", Journal of Operations Management, Vol. 20, No. 2, pp. 121-134.

Gupta, V. (2011), "Corporate Response to Global Financial Crisis: A Knowledge-Based Model”, Global Economy Journal, Vol. 11, No. 2, pp. 1524-5861.

Gustafsson, A. and Johnson, M.D. (2004) "Determining Attribute Importance in a Service Satisfaction Model", Journal of Service Research, Vol. 7, No. 2, pp. 124-141.

Grönroos, C. (1982) "An Applied Service Marketing Theory", European Journal of Marketing, Vol. 16, No. 7, pp. 30-41.

Grönroos, C., Heinonen, F., Isoniemi, K. and Lindholm, M. (2000) "The NetOffer model: a case example from the virtual marketspace", Management Decision, Vol. 38, No. 4, pp. 243-252.

Grönroos, C. (2001) "The perceived service quality concept - a mistake?", Managing Service Quality: An International Journal, Vol. 11, No. 3, pp. 150-152.

Grönroos, C. (2008) "Service logic revisited: who creates value? And who co-creates?", European Business Review, Vol. 20, No. 4, pp. 298-314.

Hakanen, T. and Jaakkola, E. (2012) "Co-creating customer-focused solutions within business networks: a service perspective", Journal of Service Management, Vol. 23, No. 4, pp.593-611.

Harkonen, J., Haapasalo, H. and Hanninen, K. (2015) "Productisation: A Review and Research Agenda", International Journal of Production Economics, Vol. 164, pp. 65-82.

Harris, H. (2001) "Content Analysis of Secondary Data: A Study of Courage in Managerial Decision Making", Journal of Business Ethics, Vol. 34, No. 3, pp 191-208.

Heaslip, G. (2013) "Services operations management and humanitarian logistics", Journal of Humanitarian Logistics and Supply Chain Management, Vol. 3, No. 1, pp. 37-51.

Heaton, J. (2008) "Secondary Analysis of Qualitative Data: An Overview", Historical Social Research, Vol. 33, No.3, pp. 33-45.

Hellström, M., Wikström, R., Gustafsson, M. and Luotola, H. (2016) "The value of project execution services: a problem and uncertainty perspective", Construction Management and Economics, Available online. DOI: 10.1080/01446193.2016.1151062.

Hemple, G., Finch, J. and Pasternak, O. (2015) "Productization as a Service: Innovation through Standards in B2B Relationships" ISPIM Conference Proceedings: The International Society for Professional Innovation Management (ISPIM). The XXVI ISPIM Conference, June 14-17 2015, Budapest, Hungary, pp. 1-42. 
Hennig-Thurau, T. and Thurau, C. (2003) "Customer Orientation of Service Employees-Toward a Conceptual Framework of a Key Relationship Marketing Construct", Journal of Relationship Marketing, Vol. 2, No. 1-2, pp.23-41.

Hietala, P. (2015) "Productisation of a professional service. Case: User centered design", Thesis for Bachelor of Business Administration, Oulu University of Applied Sciences, Finland, pp. 74. <Available online> https://www.theseus.fi/handle/10024/92006

Hinds, P.S., Vogel, R.J., Clarke-Steffen, L. (1997) 'The possibilities and pitfalls of doing a secondary analysis of a qualitative data set', Qualitative Health Research, vol. 7, No.3, pp. 408-424.

Hoch, S.J. and Deighton, J. (1989) "Managing What Consumers Learn from Experience", Journal of Marketing, Vol. 53, No. 2, pp.1-20.

Hovi, R. (2011) "Productization of Professional Services in Small Businesses", Helsinki Metropolia University of Applied Sciences, Finland. pp.85. <Available online> https://www.theseus.fi/handle/10024/58839

Hyötyläinen, M. and Möller, K. (2007) "Service packaging: key to successful provisioning of ICT business solutions", Journal of Services Marketing, Vol. 21, No. 5, pp. 304-312.

Jaakkola, E. (2011), "Unraveling the practices of "productization" in professional service firms", Scandinavian Journal of Management, Vol. 27, No. 2, pp. 221-230.

Jayaram, J. and Xu, K. (2016) "Determinants of quality and efficiency performance in service operations", International Journal of Operations \& Production Management, Vol. 36, No. 3, pp.265-285.

Johne, A. and Storey, C. (1998) "New service development: a review of the literature and annotated bibliography", European Journal of Marketing, Vol. 32, No. 3/4, pp. 184-251.

Kelley, S.W (1992) "Developing customer orientation among service employees", Journal of the Academy of Marketing Science, Vol. 20, No. 1, pp.27-36.

Kim, H. (2009) "Service science for service innovation", Journal of Service Science, Vol. 1, No. 1, pp.1-7.

Kim, K-J. and Meiren, T. (2010), “New service development process”, in Salvendy, G. and Karwowski, W. (Eds), Introduction to Service Engineering, Wiley, Hoboken, NJ, pp. 253-267.

Kim, S., Yoon, B. (2012) "Developing a process of concept generation for new product-service systems: a QFD and TRIZ-based approach", Service Business, Vol. 6, No. 3, pp.323-348.

Kindström, D. and Kowalkowski, (2014) "Service innovation in product-centric firms: A multidimensional business model perspective", Journal of Business \& Industrial Marketing, Vol. 29, No. 2, pp.96-111.

Kingman-Brundage, J., George, W.R. and Bowen, D.E. (1995) "“Service logic": achieving service system integration", International Journal of Service Industry Management, Vol. 6, No. 4, pp. 20-39.

Kitchenham, B. (2004) "Procedures for Performing Systematic Reviews". Technical Report TR/SE-0401, Keele University.

Korpi, J. (2012) "Productization of services for Paakkola Conveyor Care Services", Lapland University of Applied sciences, Kemi, Finland. pp. 85. <Available online> https://www.theseus.fi/handle/10024/42222

Korpi, E. (2008) "Contingency theoretical approach to harmonization of service operations", Faculty of Information and Natural Sciences, Helsinki University of Technology, Helsinki. pp.103. <Available online> http://www.lrg.tkk.fi/?q=content/contingency-theoretical-approach-harmonization-service-operations

Kristinsson, K., Rao, R. (2008) "Interactive Learning or Technology Transfer as a Way to Catch-Up? Analysing the Wind Energy Industry in Denmark and India", Industry and Innovation, Vol. 15, No. 3, pp. 297-320.

Kwak, k., Kim, W. (2016) "Effect of service integration strategy on industrial firm performance", Journal of Service Management, Vol. 27, No. 3, pp.391-430.

Kääriäinen, V. (2013) "Productization of Services - a case study of Lemminkäinen Group", Laurea University of Applied Sciences, Espoo, Finland. pp. 56. <Available online> https://publications.theseus.fi/handle/10024/63434

Lehtola, T. (2014) "Productisation Case Kasve Ltd." Savonia University of Applied Sciences, Kuopio, Finland. pp. 53.

<Available online> http://www.theseus.fi/handle/10024/82685

Lehtonen, M.H., Jarvi, K. and Tuominen, T. (2015) "Reflexivity in the 'productisation' of services", International Journal of Work Innovation, Vol. 1, No. 2, pp. 161-184.

Leon, N. and Davies, A. (2008) "Managed service paradox", IBM Systems Journal, Vol. 47, No. 1, pp. 153-166.

Levitt, T. (1976) “The Industrialization of Service,’ Harvard Business Review, Vol. 54, No. 5, pp. 63-74.

Liedtka, J.M. (1992) "Exploring Ethical Issues Using Personal Interviews", Business Ethics Quarterly, Vol. 2, No. 2, pp. $161-181$.

Lightfoot, H.W. and Gebauer, H. (2011) "Exploring the alignment between service strategy and service innovation", Journal of Service Management, Vol. 22, No. 5, pp.664-683.

Lincoln, Y.S. and Guba, E.G. (1986) "But is it rigorous? Trustworthiness and authenticity in naturalistic evaluation", New Directions for Program Evaluation, Vol. 30, pp.73-84.

Lukka, K. and Partanen, V. (2014) "The Role of Managerial Interventions and Organizational Ideologies in Advancing Radical Change", Journal of Change Management, Vol. 14, No. 1, pp. 66-98.

Lusch, R.F. (2011) "Reframing Supply Chain Management: A Service-Dominant Logic Perspective", Journal of supply chain management, Vol. 47, No. 1, pp.14-18.

Mattila, O., Toppinen, A., Tervo, M., and Berghäll, S. (2013), "Non-industrial Private Forestry Service Markets in a Flux: Results from a Qualitative Analysis on Finland”, Small-scale Forestry, Vol. 12, No. 4, pp. 559-578. 
Menor, L.J., Tatikonda, M.V. and Sampson, S.E. (2002) "New service development: areas for exploitation and exploration", Journal of Operations Management, Vol. 20, No. 2, pp. 135-157.

Miles, M.B., Hubermann, A.M., (1994) "Qualitative Data Analysis: An Expanded Sourcebook", second ed. Sage, Thousand Oaks, CA.

Nachmias, D. and Nachmias, C. (1987) "Research Methods in the Social Sciences", Third Edition, St. Martin's Press, New York, pp. 589.

Nagy, S. (2013) "Service Pyramid Concept of Knowledge Intensive Business Services in the Small and Medium Sized Enterprises Sector", International Journal of Advanced Computer Science and Applications, Vol. 4, No. 11, pp. 103-108.

Newman, A., Prajogo, D. and Atherton, A. (2016) "The influence of market orientation on innovation strategies", Journal of Service Theory and Practice, Vol. 26, No. 1, pp. 72-90.

Patterson, P.G. and Spreng, R.A. (1997) "Modelling the relationship between perceived value, satisfaction and repurchase inte ntions in a business-to-business, services context: an empirical examination", International Journal of Service Industry Management, Vol. 8, No. 5, pp.414-434.

Patton, M.Q. 2002, Qualitative Research and Evaluation Methods, 3rd edition, Thousand Oaks, Sage Publications.

Pekkarinen, S. and Ulkuniemi, P. (2008) "Modularity in developing business services by platform approach", The International Journal of Logistics Management, Vol. 19, No. 1, pp. 84-103.

Pinho, N., Beirão, G., Patrício, L., Fisk, R.P. (2014) "Understanding value co-creation in complex services with many actors", Journal of Service Management, Vol. 25, No. 4, pp.470-493.

Prilla, M., Schermann, M., Reuter, U., Herrmann, T., Krcmar, H. and Burr, W. (2012) "Organizing International Service Management: The Case of M-BETA", In eds. Böhmann, T., Burr, W., Herrmann, T. and Krcmar, H., Implementing International Services, Gabler Verlag, Springer, pp 213-227.

Rahikka, E., Ulkuniemi, P. and Pekkarinen, S. (2011) "Developing the value perception of the business customer through service modularity", Journal of Business \& Industrial Marketing, Vol. 26, No. 5, pp. 357-367.

Ritala, P., Hyötylä, M., Blomqvista, K. and Kosonen, M. (2013) "Key capabilities in knowledge-intensive service business", The Service Industries Journal, Vol. 33, No. 5, pp. 486-500.

Roos, I. and Edvardsson, B. (2008) "Customer-support service in the relationship perspective", Managing Service Quality: An International Journal, Vol. 18, No. 1, pp.87- 107.

Roth, A.V. and Menor, L.J. (2003) "Insights into Service Operations Management: a Research Agenda", Production and Operations Management, Vol. 12, No. 2, pp. 145-164.

Saarela, M., Muhos, M. and Niinikoski, E-R. (2013) "Best Practices in Public Business Services — Three Regional Cases", Journal of US-China Public Administration, Vol. 10, No. 4, pp. 388-397.

Saarela, M., Niinikoski, E.-R., Muhos, M. (2014) "Public business services fostering growth - case studies in northern sparsely populated areas", International Journal of Innovation and Regional Development, Vol. 5, No. 4-5, pp.367-383.

Salmi, P., Torkkeli, M., Ojanen, V., Hilmola, O.-P. (2008) "New product creation process of KIBS firms: A case study", International Journal of Services and Standards, Vol. 4, No. 1, pp.16-32.

Samaddar, S., Nargundkar, S., Daley, M. (2006) "Inter-organizational information sharing: The role of supply network configuration and partner goal congruence", European Journal of Operational Research, Vol. 174, No. 2, pp. $744-765$.

Shostack, G.L. (1984) "Designing Services That Deliver”, Harvard Business Review, Vol. 62, (January-February), pp.133-139

Silvestro, R. (1999) "Positioning services along the volume-variety diagonal: The contingencies of service design, control and improvement", International Journal of Operations \& Production Management, Vol. 19, No. 4, pp.399-421.

Simula, H., Lehtimäki, T. and Salo, J. (2008), "Re-thinking the product - from innovative technology to productized offering", Proceedings of the 2008 International Society for Professional Innovation Management Conference (XIX ISPIM), Tours, France, June 15-18.

Skalen, P., Hackley, C. (2011) "Marketing-as-practice", Scandinavian Journal of Management, Vol. 27, No. 2, pp.189-195.

Slater, S.F., Mohr, J.J. and Sengupta, S. (2010) "Market Orientation", In Wiley International Encyclopedia of Marketing: Marketing strategy, Vol. 1, eds. Peterson R.A. and Kerin, R.A., Chichester, UK, Wiley \& Sons.

Strauss, A. and Corbin, J. (1997) Grounded Theory in Practice, Sage, London.

Suominen, A., Kantola, J. and Tuominen, A. (2009), "Reviewing and defining productization”, in Huizingh, E., Torkkeli, M., Conn, S. and Bitran, I. (Eds), Proceedings of the XX ISPIM Conference, ISPIM, Vienna, June 21-24, pp. 63-85.

Szabo, V. and Strang, V.R. (1997) "Secondary analysis of qualitative data", Advances in Nursing Science, vol. 20, No. 2, pp. 6674.

Teare, R., Ingram, H., Scheuing, E., Armistead, C. (1997) "Organizational teamworking frameworks: evidence from UK and USA - based firms", International Journal of Service Industry Management, Vol. 8, No. 3, pp.250-263.

Tervola, T. (2010) "Developing a productization model for Business-to-Business services as a means to enhance sales efficiency", Helsinki University of Technology, Finland. pp. 88. <Available online> http://www.e-sales.fi/wpcontent/uploads/2011/05/thesis_tervola_final.pdf

Thomas, D.R. (2006) "A General Inductive Approach for Analyzing Qualitative Evaluation Data", American Journal of Evaluation, Vol. 27, No. 2, pp.237-246.

Thorne, S. (1990) "Secondary analysis in qualitative research: issues and implications". In Critical Issues in Qualitative Research Methods, Edited by: Morse, J. M. London: Sage. 
Tolonen, A. (2016) "Product Portfolio Management over Horizontal and Vertical Portfolios", Doctoral thesis, Acta Universitatis Ouluensis, C Technica 574, University of Oulu, Finland. <Available online> http://jultika.oulu.fi/files/isbn9789526212678.pdf

Tuunanen, T. and Cassab, H. (2011) "Service Process Modularization: Reuse Versus Variation in Service Extensions", Journal of Service Research, Vol. 14, No. 3, pp. 340-354.

Tuunanen, T., Bask, A. and Merisalo-Rantanen, H. (2012) "Typology for Modular Service Design: Review of Literature", International Journal of Service Science, Management, Engineering, and Technology, Vol. 3, No. 3, pp. 99-112.

Ukko, J., Pekkola, S., Valtonen, J., Saunila, M. and Rantanen, H. (2011) "Productising expert services of performance management", International Journal of Business Excellence, Vol. 4, No. 2, pp. 125-141.

Ulkuniemi, P. and Pekkarinen, S. (2011) "Creating value for the business service buyer through modularity", Journal of Services and Operations Management, Vol. 8, No. 2, pp.127-141.

Valminen, K., and Toivonen, M. (2012), "Seeking efficiency through productisation: A case study of small KIBS participating in a productisation project”, Service Industries Journal, Vol. 32, No. 2, pp. 273-289.

Valtakoski, A. and Järvi, K. (2016),"Productization of knowledge-intensive services: enabling knowledge sharing and cross-unit collaboration", Journal of Service Management, Vol. 27, No. 3, pp. 360-390.

Van der Aa, W. and Elfring, T. (2002) "Realizing innovation in services", Scandinavian Journal of Management, Vol. 18, No. 2, pp.155-171.

Varimo, H. (2013) "Packaging of Technical Services in Social and Health Care Services", Master's thesis, Department of Industrial Management, Lappeenranta University of Technology, Finland, pp.97. <Available online> http://urn.fi/URN:NBN:fife201304082711

Virtanen, T. (2013) "Productizing professional consultancy services modularly through service blueprinting: Case QPR Software", Master's Thesis, Lappeenranta University of Technology, Finland. pp.101. <Available online> http://urn.fi/URN:NBN:fife201304293354

Voss, C.A. and Hsuan, J. (2009) "Service Architecture and Modularity", Decision Sciences, Vol. 40, No. 3, pp. 541-569.

Wallace, C.M., Eagleson, G., Waldersee, R. (2000) "The sacrificial HR strategy in call centers", International Journal of Service Industry Management, Vol. 11, No. 2, pp.174-184.

Wang, Q., Zhao, X. and Voss, C. (2016) "Customer orientation and innovation: A comparative study of manufacturing and service firms", International Journal of Production Economics, Vol. 171, Part 2, pp. 221-230.

Wang, X. (2011) "The Effect of Unrelated Supporting Service Quality on Consumer Delight, Satisfaction, and Repurchase Intentions", Journal of Service Research, Vol. 14, No. 2, pp. 149-163.

Ylitalo, Janne (2011) "Productization process of services in telecommunication industry - Case Octopus Network" Master's Thesis. Lapland University of Applied Sciences, Finland, pp. 83. <Available Online> http://urn.fi/URN:NBN:fi:amk-201105056364 
Appendix A. Secondary data concerning service productisation-thirteen instances of SP

\begin{tabular}{|c|c|c|c|c|c|}
\hline $\begin{array}{l}\text { Instance } \\
\text { of SP } \\
\text { activities }\end{array}$ & Service & Analysed unit & \# of Interviewees & Additional methods & Origin \\
\hline A & $\begin{array}{l}\text { Expert services for } \\
\text { product development, } \\
\text { contract manufacturing, } \\
\text { B2B marketing, and } \\
\text { business development }\end{array}$ & $\begin{array}{l}\text { Consultancy company in } \\
\text { the pharmaceutical and } \\
\text { healthcare industry }\end{array}$ & Managing director & $\begin{array}{l}\text { Analysing tools, guidelines and } \\
\text { documentation } \\
\text { Workshop on service components }\end{array}$ & (Lehtola, 2014) \\
\hline $\mathrm{B}$ & $\begin{array}{l}\text { Service package for } \\
\text { coaching organisational } \\
\text { citizenship }\end{array}$ & $\begin{array}{l}\text { A company focusing on } \\
\text { providing professional } \\
\text { services }\end{array}$ & - & $\begin{array}{l}\text { Competition analysis } \\
\text { Questionnaire to potential } \\
\text { customers, a sample of \#25 }\end{array}$ & (Hovi, 2011) \\
\hline $\mathrm{C}$ & $\begin{array}{l}\text { Care services for } \\
\text { industrial conveyor } \\
\text { systems }\end{array}$ & Care services & $\begin{array}{l}\text { \#Meetings \#Employee } \\
\text { interviews }\end{array}$ & $\begin{array}{l}\text { Analysis of company brochures } \\
\text { Benchmarking }\end{array}$ & (Korpi, 2012) \\
\hline $\mathrm{D}$ & $\begin{array}{l}\text { Hospitality at a sports } \\
\text { arena }\end{array}$ & $\begin{array}{l}\text { Service provider whose } \\
\text { business entails renting a } \\
\text { VIP box at a sports arena. } \\
\text { Customer experience. }\end{array}$ & $\begin{array}{l}\text { Owner } \\
\text { VIP host } \\
5 \text { customers individually }\end{array}$ & Observation & (Aravirta, 2010) \\
\hline $\mathrm{E}$ & $\begin{array}{l}\text { Care and managed } \\
\text { services }\end{array}$ & $\begin{array}{l}\text { Care and managed } \\
\text { services by a company } \\
\text { providing } \\
\text { telecommunication } \\
\text { networks }\end{array}$ & $\begin{array}{l}\text { Total of } 12 \text { persons with } \\
\text { adequate understanding of } \\
\text { service operations }\end{array}$ & $\begin{array}{l}\text { Internal presentations and process } \\
\text { sheets } \\
\text { Validation in two workshops }\end{array}$ & (Korpi, 2008) \\
\hline $\mathrm{F}$ & Service desk services & $\begin{array}{l}\text { Service desk of a company } \\
\text { focusing on infrastructure } \\
\text { and building construction }\end{array}$ & \#Interviews & Questionnaire & (Kääriäinen, 2013) \\
\hline G & $\begin{array}{l}\text { Maintenance and repair } \\
\text { services }\end{array}$ & $\begin{array}{l}\text { Maintenance and repair } \\
\text { services of a company } \\
\text { providing elevators and } \\
\text { escalators }\end{array}$ & $\begin{array}{l}\text { Total of } 12 \text { persons in an } \\
\text { area-level organisation }\end{array}$ & $\begin{array}{l}\text { Internal presentations and } \\
\text { process sheets }\end{array}$ & (Korpi, 2008) \\
\hline $\mathrm{H}$ & Professional services & Planning office & \#of Interviews & Observation & (Hietala, 2015) \\
\hline I & IT services & $\begin{array}{l}\text { IT services sales of one of } \\
\text { the leading IT outsourcing } \\
\text { providers globally }\end{array}$ & $\begin{array}{l}\text { Total of } 34 \text { semi-structured } \\
\text { interviews }\end{array}$ & Company documentation & (Tervola, 2010) \\
\hline $\mathrm{J}$ & $\begin{array}{l}\text { Care services, physical } \\
\text { and virtual }\end{array}$ & $\begin{array}{l}\text { Care services of a } \\
\text { company providing } \\
\text { mobile phones }\end{array}$ & $\begin{array}{l}\text { Total of six people in global } \\
\text { organisation }\end{array}$ & $\begin{array}{l}\text { Internal presentations and process } \\
\text { sheets }\end{array}$ & (Korpi, 2008) \\
\hline $\mathrm{K}$ & $\begin{array}{l}\text { Technical services for } \\
\text { Social and Health } \\
\text { Services provided by } \\
\text { municipalities }\end{array}$ & Technical services & $\begin{array}{l}\text { Three semi-structured } \\
\text { interviews }\end{array}$ & $\begin{array}{l}\text { Observation, Documentations, } \\
\text { Questionnaire sample of \#11 }\end{array}$ & (Varimo, 2013) \\
\hline $\mathrm{L}$ & $\begin{array}{l}\text { Professional consultancy } \\
\text { services }\end{array}$ & $\begin{array}{l}\text { Company, a project } \\
\text { focusing on productisation }\end{array}$ & $\begin{array}{l}\text { Three semi-structured } \\
\text { interviews with key } \\
\text { personnel }\end{array}$ & $\begin{array}{l}\text { Company reports, Company's } \\
\text { process mappings, Internal } \\
\text { documentations and guidelines. }\end{array}$ & (Virtanen 2013) \\
\hline M & Telecom testing services & $\begin{array}{l}\text { Company, productisation } \\
\text { project }\end{array}$ & $\begin{array}{l}\text { Five semi-structured } \\
\text { interviews with managerial } \\
\text { level people, a representative } \\
\text { of board of directors }\end{array}$ & $\begin{array}{l}\text { Observation, documentation, } \\
\text { reports }\end{array}$ & (Ylitalo, 2011) \\
\hline
\end{tabular}

*The instances of SP involve secondary data originating from unpublished university theses 